Fast heterogeneous loss of $\mathrm{N} 2 \mathrm{O} 5$ leads to significant nighttime

NOx removal and nitrate aerosol formation at a coastal

background environment of southern China

\title{
Yan, Chao
}

2019-08-10

Yan , C , Tham , Y J , Zha , Q , Wang , X , Xue , L , Dai , J , Wang , Z \& Wang , T 2019 , ' Fast heterogeneous loss of $\mathrm{N} 2 \mathrm{O} 5$ leads to significant nighttime NOx removal and nitrate aerosol formation at a coastal background environment of southern China ' , The Science of the Total Environment , vol. 677 , pp. 637-647 . https://doi.org/10.1016/j.scitotenv.2019.04.389

http://hdl.handle.net/10138/329446

https://doi.org/10.1016/j.scitotenv.2019.04.389

cc_by_nc_nd

acceptedVersion

Downloaded from Helda, University of Helsinki institutional repository.

This is an electronic reprint of the original article.

This reprint may differ from the original in pagination and typographic detail.

Please cite the original version. 


\section{Accepted Manuscript}

Fast heterogeneous loss of N2O5 leads to significant nighttime NOx removal and nitrate aerosol formation at a coastal background environment of southern China

Chao Yan, Yee Jun Tham, Qiaozhi Zha, Xinfeng Wang, Likun Xue, Jianing Dai, Zhe Wang, Tao Wang

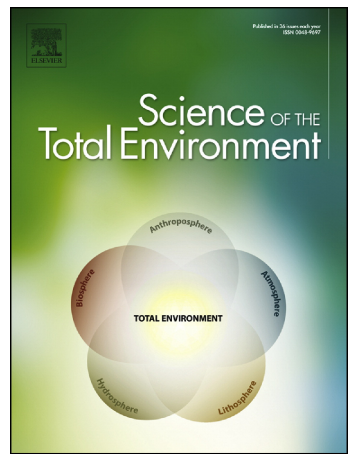

PII: S0048-9697(19)31934-5

DOI: https://doi.org/10.1016/j.scitotenv.2019.04.389

Reference: STOTEN 32097

To appear in: Science of the Total Environment

Received date: 10 February 2019

Revised date: 25 April 2019

Accepted date: 26 April 2019

Please cite this article as: C. Yan, Y.J. Tham, Q. Zha, et al., Fast heterogeneous loss of N2O5 leads to significant nighttime NOx removal and nitrate aerosol formation at a coastal background environment of southern China, Science of the Total Environment, https://doi.org/10.1016/j.scitotenv.2019.04.389

This is a PDF file of an unedited manuscript that has been accepted for publication. As a service to our customers we are providing this early version of the manuscript. The manuscript will undergo copyediting, typesetting, and review of the resulting proof before it is published in its final form. Please note that during the production process errors may be discovered which could affect the content, and all legal disclaimers that apply to the journal pertain. 


\title{
Fast heterogeneous loss of $\mathrm{N}_{2} \mathrm{O}_{5}$ leads to significant nighttime $\mathrm{NO}_{x}$ removal and nitrate aerosol formation at a coastal background environment of southern China
}

\author{
Chao Yan ${ }^{1,2 \sharp}$, Yee Jun Tham ${ }^{1,2^{\ddagger}}$, Qiaozhi Zha ${ }^{1,2}$, Xinfeng Wang ${ }^{3}$, Likun Xue ${ }^{3}$, Jianing Dai ${ }^{1}$, Zhe \\ Wang ${ }^{1}$ and Tao Wang ${ }^{1, *}$
}

1 Department of Civil and Environmental Engineering, The Hong Kong Polytechnic University, Hong Kong, China

2 Institute for Atmospheric and Earth System Research/Physics, University of Helsinki, 00014, Helsinki,

Finland;

3 Environment Research Institute, Shandong University, Jinan, Shandong, China;

\# These authors have contributed equally to this work

* Correspondence: tao.wang@polyu.edu.hk; Tel.: +852-2766-6059

\begin{abstract}
Nitrate radical $\left(\mathrm{NO}_{3}\right)$ and dinitrogen pentoxide $\left(\mathrm{N}_{2} \mathrm{O}_{5}\right)$ play crucial roles in the nocturnal atmosphere. To quantify their impacts, we deployed a thermal-dissociation chemical ionization mass spectrometry (TD-CIMS), to measure their concentration, as well as $\mathrm{ClNO}_{2}$ at a coastal background site in the southern of China during the late autumn of 2012. Moderate levels of $\mathrm{NO}_{3}, \mathrm{~N}_{2} \mathrm{O}_{5}$ and high concentration of $\mathrm{ClNO}_{2}$ were observed during the study period, indicating active $\mathrm{NO}_{x}-\mathrm{O}_{3}$ chemistry in the region. Distinct features of $\mathrm{NO}_{3}, \mathrm{~N}_{2} \mathrm{O}_{5}$ and $\mathrm{ClNO}_{2}$ mixing ratios were observed in different airmasses. Further analysis revealed that the $\mathrm{N}_{2} \mathrm{O}_{5}$ heterogeneous reaction was the dominant loss of $\mathrm{N}_{2} \mathrm{O}_{5}$ and $\mathrm{NO}_{3}$, which showed higher loss rate compared to that in other coastal sites. Especially, the $\mathrm{N}_{2} \mathrm{O}_{5}$ loss rates could reach up to $0.0139 \mathrm{~s}^{-1}$ when airmasses went across the sea. The fast heterogeneous loss of $\mathrm{N}_{2} \mathrm{O}_{5}$ led to rapid $\mathrm{NO}_{x}$ loss which could be comparable to the daytime process through $\mathrm{NO}_{2}$ oxidization by $\mathrm{OH}$, and on the other hand, to rapid nitrate aerosol formation. In summary, our results
\end{abstract}


revealed that the $\mathrm{N}_{2} \mathrm{O}_{5}$ hydrolysis could play significant roles in regulating the air quality by reducing $\mathrm{NO} \times$ but forming nitrate aerosols.

Keywords: dinitrogen pentoxide, TD-CIMS, $\mathrm{N}_{2} \mathrm{O}_{5}$ heterogeneous reaction, $\mathrm{NO}_{x}$ removal, nitrate aerosols

\section{Highlights:}

1. $\mathrm{N}_{2} \mathrm{O}_{5}$ and $\mathrm{NO}_{3}$ were observed with distinct features in different airmasses.

2. The fast hydrolysis of $\mathrm{N}_{2} \mathrm{O}_{5}$ dominated the loss of $\mathrm{N}_{2} \mathrm{O}_{5}$ and $\mathrm{NO}_{3}$, particularly when continental air went across the sea before reaching the station.

3. The fast loss of $\mathrm{N}_{2} \mathrm{O}_{5}$ can contribute to a significant fraction of $\mathrm{NO}_{x}$ removal and nitrate aerosol formation.

\section{Introduction}

Nitrogen oxides $\left(\mathrm{NO}_{\mathrm{x}}=\mathrm{NO}+\mathrm{NO}_{2}\right)$, largely emitted by human activities, are key species in a number of atmospheric processes and therefore have crucial impact on climate and human health. In the daytime, $\mathrm{NO}_{x}$ play key roles in regulating ozone formation (Wang et al., 2006;Wang et al., 2010), participating in the formation of highly oxygenated molecules (Yan et al., 2016;Lee et al., 2016) and subsequent formation secondary organic aerosol (Hoyle et al., 2011), as well as leading to direct formation of inorganic nitrate aerosol $\left(\mathrm{NO}_{3}^{-}\right)$by reacting with hydroxyl radical $(\mathrm{OH})$ to form water soluble nitric acid $\left(\mathrm{HNO}_{3}, \mathrm{R} 1\right)$, and the $\mathrm{R} 1$ has been recognized as the termination of $\mathrm{NO}_{x}$ cycle in the atmosphere (e.g. (Ramanathan et al., 2001))

$$
\mathrm{NO}_{2}+\mathrm{OH} \rightarrow \mathrm{HNO}_{3}
$$


At night, $\mathrm{NO}_{x}$ can participate in a different set of atmospheric processes. Oxidation of $\mathrm{NO}_{2}$ by $\mathrm{O}_{3}$ produces nitrate radical $\left(\mathrm{NO}_{3}, \mathrm{R} 2\right)$, a major oxidation in the nocturnal boundary layer. It can oxidize various volatile organic compounds (VOC, R3), producing oxygenate products, which can contribute to the formation of organic aerosols (Lucas and Prinn, 2005;Rollins et al., 2009;Ng et al., 2017). Another competing reaction is that $\mathrm{NO}_{3}$ further reacts with $\mathrm{NO}_{2}$ to form $\mathrm{N}_{2} \mathrm{O}_{5}$, after which $\mathrm{NO}_{3}$ and $\mathrm{N}_{2} \mathrm{O}_{5}$ can establish a fast thermal equilibrium ( $\left.\mathrm{R} 4, \mathrm{R} 4^{\prime}\right) . \mathrm{N}_{2} \mathrm{O}_{5}$ either deposits on aerosol surface through heterogeneous reaction to form inorganic nitrate aerosol (R5) or serves as the reservoir of $\mathrm{NO}_{3}$ and $\mathrm{NO}_{2}$ $\left(\mathrm{R} 4^{\prime}\right)$. If aerosols contain chloride $\left(\mathrm{Cl}^{-}\right)$, heterogeneous reaction of $\mathrm{N}_{2} \mathrm{O}_{5}$ may lead to the formation of $\mathrm{ClNO}_{2}(\mathrm{R} 6)$, which can further photolyze to release the chloride radical (Cl-) after sunrise (R7) and affect the atmospheric oxidation capacity (Tham et al., 2014).

$$
\begin{aligned}
& \mathrm{NO}_{2}+\mathrm{O}_{3} \rightarrow \mathrm{NO}_{3}+\mathrm{O}_{2} \\
& \mathrm{NO}_{3}+\mathrm{VOC} \rightarrow \text { Products } \\
& \mathrm{NO}_{2}+\mathrm{NO}_{3}+\mathrm{M} \rightarrow \mathrm{N}_{2} \mathrm{O}_{5}+\mathrm{M} \\
& \mathrm{N}_{2} \mathrm{O}_{5}+\mathrm{M} \rightarrow \mathrm{NO}_{2}+\mathrm{NO}_{3}+\mathrm{M} \\
& \mathrm{N}_{2} \mathrm{O}_{5}+\mathrm{H}_{2} \mathrm{O}(\mathrm{s}) \rightarrow 2 \mathrm{HNO}_{3} \\
& \mathrm{~N}_{2} \mathrm{O}_{5}+\mathrm{Cl}^{-} \rightarrow \mathrm{ClNO}_{2}+\mathrm{NO}_{3}^{-} \\
& \mathrm{ClNO}_{2}+h v \rightarrow \mathrm{Cl} \cdot+\mathrm{NO}_{2}
\end{aligned}
$$

These nocturnal processes essentially convert $\mathrm{NO}_{x}$ into nitrate constituents in aerosols, causing a reduction in $\mathrm{NO}_{\mathrm{x}}$ and an augment secondary aerosol mass concentration, which however, remain poorly quantified.

A major challenge in estimating the importance of these reactions is the large uncertainty of the $\mathrm{N}_{2} \mathrm{O}_{5}$ heterogeneous uptake coefficient of $\mathrm{N}_{2} \mathrm{O}_{5}\left(\gamma_{\mathrm{N}_{2} \mathrm{O}_{5}}\right)$, an important parameter for estimating the $\mathrm{N}_{2} \mathrm{O}_{5}$ heterogeneous loss rate $\left(k_{\mathrm{N} 2 \mathrm{O} 5}\right.$; see Eq 1$)$ : 


$$
k_{\mathrm{N}_{2} \mathrm{O}_{5}}=0.25 \times \mathrm{S}_{\mathrm{a}} \times \mathrm{C} \times \gamma_{\mathrm{N}_{2} \mathrm{O}_{5}}
$$

Here, $S_{a}$ is the surface area of aerosol and $c$ is the molecular velocity of $\mathrm{N}_{2} \mathrm{O}_{5}$. Both field and laboratory studies have shown that the $\gamma_{N_{2} O_{5}}$ values fall between ca. $0.001-0.2$. However, the $\gamma_{N_{2} O_{5}}$ may significantly vary depending on the chemical composition of particles (Brown et al., 2006;Ammann et al., 2013;Brown and Stutz, 2012;Tang et al., 2017). For instance, chloride and water content in the aerosol promote $\mathrm{N}_{2} \mathrm{O}_{5}$ heterogeneous uptake while, nitrate and organic coating inhibit the heterogeneous uptake of $\mathrm{N}_{2} \mathrm{O}_{5}$ (Riedel et al., 2012; Tham et al., 2018;Bertram and Thornton, 2009). The mixing status and the diffusive length of the chemical compounds in the aerosol may also play crucial role in affecting the $\mathrm{N}_{2} \mathrm{O}_{5}$ heterogeneous uptake (Gaston and Thornton, 2016;Gaston et al., 2014;Ryder et al., 2014). Despite of these new insights, most chemical transfer models derived from the laboratory studies failed to reproduce the field determined $\gamma_{N_{2} O_{5}}$ (McDuffie et al., 2018), indicating that the complexity of heterogeneous uptake of $\mathrm{N}_{2} \mathrm{O}_{5}$ remains incompletely understood.

Measurements of $\mathrm{N}_{2} \mathrm{O}_{5}$ and its loss process either through $\mathrm{N}_{2} \mathrm{O}_{5}$ heterogeneous reaction or $\mathrm{NO}_{3}$ loss reactions (term as $\mathrm{N}_{2} \mathrm{O}_{5}$ reactivity) have been the interest of many field studies in different places around the world over the past decade. For examples, Brown et al. (2003) reported the first simultaneous in situ measurement of a suite of nocturnal nitrogen oxide compounds in Boulder, Colorado, and $\mathrm{N}_{2} \mathrm{O}_{5}$ reached a peak concentration of nearly 3 ppbv under polluted conditions (Brown et al., 2003a;Brown et al., 2003b). Brown and co-workers then tracked the $\mathrm{N}_{2} \mathrm{O}_{5}$ reactivity through a flight measurement in New England and found that the $\mathrm{N}_{2} \mathrm{O}_{5}$ heterogeneous loss dominated the $\mathrm{N}_{2} \mathrm{O}_{5}$ sink and its lifetime in the polluted airmasses with high sulfate aerosol loading was two orders of magnitude shorter than in relatively cleaner airmasses from eastern Pennsylvania and New Jersey (Brown et al., 2006). A cruise measurement along the United States east coast showed more variation in the $\mathrm{N}_{2} \mathrm{O}_{5}$ reactivity where $\mathrm{N}_{2} \mathrm{O}_{5}$ heterogeneous loss dominated the $\mathrm{N}_{2} \mathrm{O}_{5}$ sink in the outflow airmasses during the night but $\mathrm{N}_{2} \mathrm{O}_{5}$ loss through the $\mathrm{NO}_{3}$ sink become more important in airmasses characterized 
with higher level of terrestrially emitted biogenic VOC (Aldener et al., 2006). Another nighttime aircraft measurement downwind of urban, industrial and rural areas of Texas revealed that the $\mathrm{N}_{2} \mathrm{O}_{5}$ heterogeneous loss was of less importance ( $14-28 \%$ of the total reactivity) compared to the $\mathrm{NO}_{3}$ reaction with VOC (Brown et al., 2011). Similar studies were also conducted in Europe, where Crowley et al. (2011) observed at a coastal site in southern Spain that the $\mathrm{NO}_{3}$ loss reaction was prevailing in the marine airmasses, in contrast to the $\mathrm{N}_{2} \mathrm{O}_{5}$-dominated losses in the continental originated airmasses. An airborne $\mathrm{N}_{2} \mathrm{O}_{5}$ measurement in $\mathrm{UK}$ also showed that the $\mathrm{N}_{2} \mathrm{O}_{5}$ heterogeneous loss was faster than $\mathrm{NO}_{3}$ loss rate aloft the Southern North Sea, while, the $\mathrm{NO}_{3}$ loss was dominating in the air above the motorway, Greater London and English Channel (Morgan et al., 2015). As in Asia, Matsumoto et al. (2006) reported that the $\mathrm{NO}_{3}$ loss accounted for $65-74 \%$ of the total loss rate of $\mathrm{N}_{2} \mathrm{O}_{5}$ in Japan. Recent studies reported intense $\mathrm{N}_{2} \mathrm{O}_{5}$ heterogeneous uptake and dominating the $\mathrm{N}_{2} \mathrm{O}_{5}$ loss in the northern polluted regions of China (Tham et al., 2016;Wang et al., 2017a;Wang et al., 2017b;Wang et al., 2017c). These measurements have revealed the spatial variations in the $\mathrm{N}_{2} \mathrm{O}_{5} / \mathrm{NO}_{3}$ reactivity around the world, indicating that the role of $\mathrm{N}_{2} \mathrm{O}_{5}$ can vary significantly over different environment and airmasses.

Hong Kong, one of the most urbanized coastal cities in Pearl River Delta (PRD), has been suffering from severe photochemical pollutions that are characterized by high mixing ratios of $\mathrm{NO}_{x}$ and $\mathrm{O}_{3}$ (Wang et al., 2009a). Under such circumstances, the importance of $\mathrm{N}_{2} \mathrm{O}_{5}$ and $\mathrm{NO}_{3}$ may be amplified in this environment, where pollution is typically distinctive in the airmasses from the inland of China compared to the inflows of marine air (Wang et al., 2003;Wang et al., 2005). Indeed, very high levels of $\mathrm{N}_{2} \mathrm{O}_{5}$ and $\mathrm{ClNO}_{2}$, up to 7.7 and 4.7 ppbv, respectively, were observed at a mountain-top site in Hong Kong (Brown et al., 2016; Wang et al., 2016), and the $\mathrm{NO}_{3} / \mathrm{N}_{2} \mathrm{O}_{5}$ chemistry removed $70 \%$ of the $\mathrm{NO}_{x}$ in the nocturnal residual layer and ultimately (Yun et al., 2017), perturbing the $\mathrm{NO}_{x}$ and $\mathrm{O}_{3}$ level in the next day (Wang et al., 1998). Elevated levels ( 2 ppbv) of $\mathrm{ClNO}_{2}$ were also observed at a coastal and ground-level site (Hok Tsui) in Hong Kong, and the photolysis of $\mathrm{ClNO}_{2}$ in the early morning led to fast production of $\mathrm{Cl}$ atoms, whose oxidative power was several times of that from ozone photolysis (Tham et al., 2014). Continuing that work, this paper analyzes nighttime reactivity $\mathrm{N}_{2} \mathrm{O}_{5}$ and $\mathrm{NO}_{3}$ in 
different airmasses arriving at the coastal site, and discusses the role of $\mathrm{N}_{2} \mathrm{O}_{5}$ heterogeneous uptake in the $\mathrm{NO}_{x}$ reduction and nitrate aerosol formation.

\section{Methods}

\subsection{Site descriptions}

The measurement took place at Hok Tsui atmospheric monitoring station which is located at the southeast tip of Hong Kong Island $\left(22.22^{\circ} \mathrm{N}, 114.25^{\circ} \mathrm{E}\right)$. Figure 1 shows the location of the study site in relation to Hong Kong urban areas and major cities in Pearl River Delta (i.e. Shenzhen, Guangzhou and Macau). The site sits on a $60 \mathrm{~m}$ high cliff (above sea level), facing the South China Sea from northeast to the west $\left(\sim 270^{\circ}\right.$ view). Hok Tsui is typically in the upwind of the urban cores of Hong Kong and PRD and there are no strong emission sources within the surrounding area (the nearest Hong Kong's urban center is approximately $15 \mathrm{~km}$ away), but can be occasionally influenced by urban plumes (e.g. (Wang et al., 1998;Xue et al., 2016)). Therefore, measurements at Hok Tsui station are expected to have a mixture of background characteristics from the ocean and airmasses transported from the urban areas, which is a suitable for investigating the reactivity of $\mathrm{NO}_{3}$ and $\mathrm{N}_{2} \mathrm{O}_{5}$ in the different air masses. More detail descriptions of the site can be found elsewhere (Cheng et al., 2000; Wang et al., 2009b;).

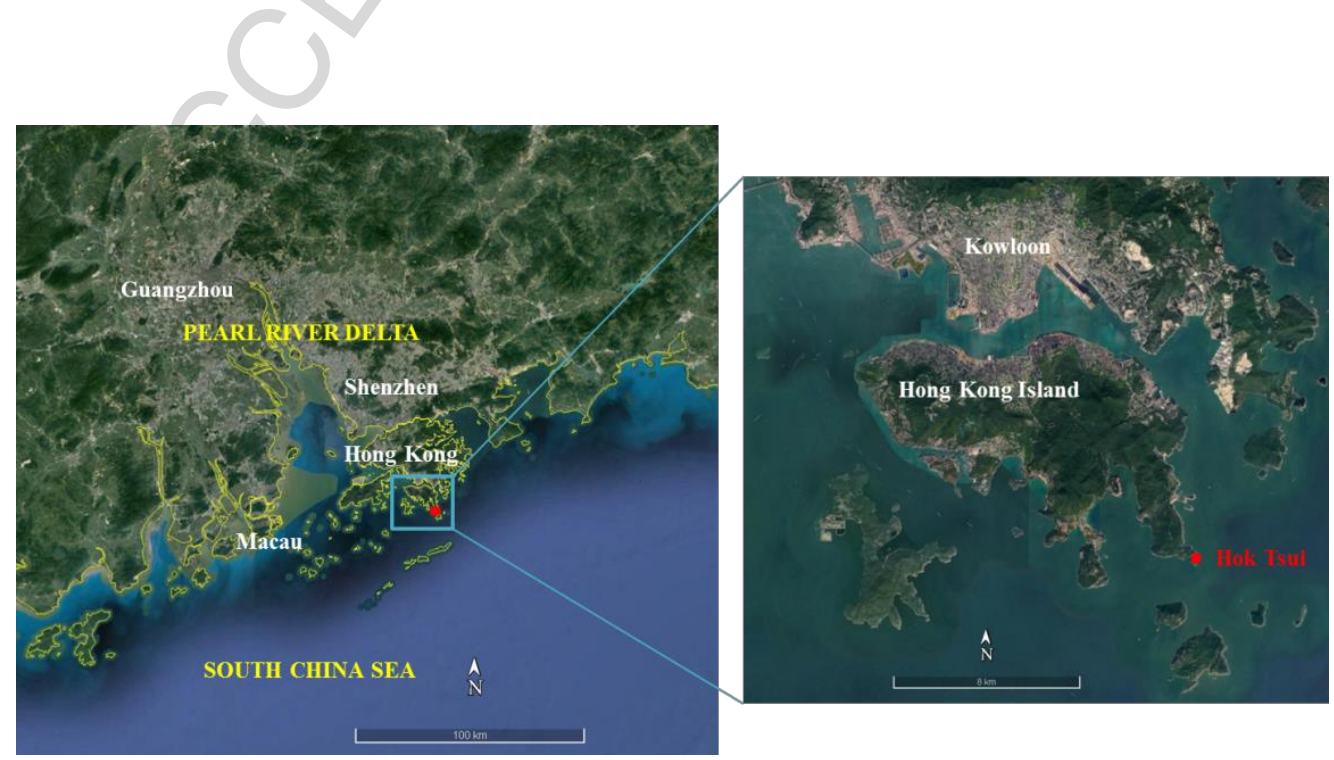


Figure 1. The location of Hok Tsui site in relative to the urbanization areas in Pearl River Delta, China.

\subsection{Measurements}

\subsubsection{Measurement of $\mathrm{NO}_{3}+\mathrm{N}_{2} \mathrm{O}_{5}$ and $\mathrm{ClNO}_{2}$}

A thermal dissociation-chemical ionization mass spectrometer (TD-CIMS) was used to measure the $\mathrm{NO}_{3}+\mathrm{N}_{2} \mathrm{O}_{5}$ and $\mathrm{ClNO}_{2}$. A 3 m length of perfluoroalkoxy (PFA) tubing (inner diameter of $9.5 \mathrm{~mm}$; outer diameter of $12.7 \mathrm{~mm}$ ) was used to draw down the ambient air at a total flow-rate of 6 standard liters per minute (SLPM), leading to a residence time of less than a second. Only 1.55 SLPM out of the total flow was sampled through a $14.8 \mathrm{~cm}$ length of heating region (heated at $180^{\circ} \mathrm{C}$ ) before entering the CIMS while the remaining flow was dumped. The $\mathrm{N}_{2} \mathrm{O}_{5}$ was thermal-dissociated into $\mathrm{NO}_{3}$ by the high inlet temperature, while the $\mathrm{ClNO}_{2}$ would be able to pass through the heating region (Thaler et al., 2011), and subsequently ionized by the reagent ions (iodide, $\mathrm{I}^{-}$) to produce $\mathrm{NO}_{3}{ }^{-}$ions (detected at 62

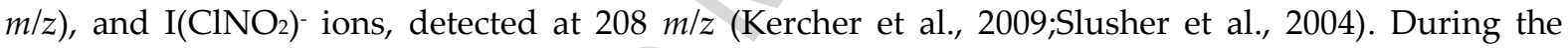
campaign, the instrument background was determined hourly by adding a small flow of high concentration of $\mathrm{NO}(\sim 1000 \mathrm{ppm})$ into the top of the sampling inlet, in order to 'titrate' the $\mathrm{NO}_{3}$ and $\mathrm{N}_{2} \mathrm{O}_{5}$, ultimately. The TD-CIMS was calibrated weekly and the average sensitivity during the campaign was determined to be $1.9 \pm 0.1 \mathrm{~Hz} /$ pptv $0.44 \pm 0.05 \mathrm{~Hz} / \mathrm{ppt}$ (mean \pm standard deviation) for $\mathrm{NO}_{3}+\mathrm{N}_{2} \mathrm{O}_{5}$ and $\mathrm{ClNO}_{2}$, respectively. The detection limit ( 1 minute average, $3 \sigma$ ) was estimated to be 10 pptv and 2 pptv for $\mathrm{NO}_{3}+\mathrm{N}_{2} \mathrm{O}_{5}$ and $\mathrm{ClNO}_{2}$, respectively. The detail sampling, detection, calibration procedures can be found in elsewhere (Wang et al., 2014; Tham et al. 2014).

It has been found that the co-existence of peroxy acetyl nitrate (PAN) and $\mathrm{NO}_{x}$ caused an overestimation of $\mathrm{NO}_{3}+\mathrm{N}_{2} \mathrm{O}_{5}$ signals $(62 \mathrm{~m} / \mathrm{z})$ in the daytime [45], but such interference was insignificant during the nighttime at Hok Tsui due to relatively low level of PAN and NOx. Therefore, only nighttime data (19:00-06:00, local time) were extracted for the analysis and the correction of such interference at the nighttime $62 \mathrm{~m} / \mathrm{z}$ data was estimated to be smaller than 15\%. Another uncertainty of this 
measurement is that the potential loss of $\mathrm{N}_{2} \mathrm{O}_{5}$ on the inlet surface (i.e., conversion to $\mathrm{ClNO}_{2}$ ) might be enhanced when particles deposited on the wall of inlet tube over time. To avoid the large uncertainty from inlet chemistry, only the data from 23 August to 19 September 2012 were used in this study. Upon checking on the ambient data during the instrument background measurements (flooding the inlet with high $\mathrm{NO}$ concentration), there is no significant reduction in the $\mathrm{ClNO}_{2}$ signal, whereas the $\mathrm{NO}_{3}+\mathrm{N}_{2} \mathrm{O}_{5}$ signal immediately dropped to zero level. This observation suggests that the inlet chemistry (conversion of $\mathrm{N}_{2} \mathrm{O}_{5}$ to $\mathrm{ClNO}_{2}$ on inlet surface) was insignificant, at least in this selected study period.

\subsubsection{Auxiliary measurements}

In addition to TD-CIMS, other ancillary measurement included the routine gases and meteorological parameters. $\mathrm{O}_{3}$ was measured with a commercial UV photometric analyzer (Model 49i, Thermo Environmental Instruments TEI, USA). $\mathrm{NO} \times\left(\mathrm{NO}\right.$ and $\mathrm{NO}_{2}$ ) was measured with a chemiluminescence instrument (Model 42i, TEI) equipped with a photolytic $\mathrm{NO}_{2}$-converter (Air Quality Design, USA), which is more suitable for measurement in rural site (Xu et al., 2012). The ambient temperature and relative humidity $(\mathrm{RH})$ were monitored with a temperature/RH probe (Model 41382VC/VF, M.R. YOUNG, USA). Wind speed and direction were monitored using a wind monitor (Gill, UK). Photolysis rate of $\mathrm{NO}_{2}$ was obtained using a filter radiometer (Meteorologie consult gmbh). All of the inlets and meteorological probes/sensors were installed close to each other to reduce inhomogeneity of the sample air.

\subsection{Estimating the steady-state $\mathrm{NO}_{3}$ and $\mathrm{N}_{2} \mathrm{O}_{5}$ loss rates}

$\mathrm{N}_{2} \mathrm{O}_{5}$ can achieve fast thermal equilibrium with $\mathrm{NO}_{3}$ and $\mathrm{NO}_{2}$ in ambient condition and can be described by using Eq. 2 and Eq. 3. 


$$
\begin{aligned}
& {\left[\mathrm{N}_{2} \mathrm{O}_{5}\right]=K_{\mathrm{eq}}\left[\mathrm{NO}_{2}\right]\left[\mathrm{NO}_{3}\right]} \\
& K_{\mathrm{eq}}=k_{4} / k_{4}^{\prime}
\end{aligned}
$$

Here, $K_{\text {eq }}$ is the thermal equilibrium, $k_{4}$ and $k_{4}{ }^{\prime}$ are the rate constant from $\mathrm{R}_{4}$ and $\mathrm{R}^{4}$, respectively; $k_{4}=1.9 \times 10^{-12}(\mathrm{~T} / 300)^{0.2} \mathrm{~cm}^{3}$ molecule $\mathrm{e}^{-1} \mathrm{~s}^{-1}($ Viggiano et al., 1981$)$ and $k_{4}^{\prime}=9.7 \times 10^{14}(\mathrm{~T} / 300)^{0.1} \exp ^{(-11080 / \mathrm{T})} \mathrm{s}^{-1}$ (Hahn et al., 2000). With the known $\mathrm{Keq}_{\mathrm{e}}\left[\mathrm{NO}_{2}\right]$, we can then calculate the $\mathrm{N}_{2} \mathrm{O}_{5}$ to $\mathrm{NO}_{3}$ ratio and separate the measured total $\mathrm{NO}_{3}+\mathrm{N}_{2} \mathrm{O}_{5}$ into individual concentrations of $\mathrm{NO}_{3}$ and $\mathrm{N}_{2} \mathrm{O}_{5}$ for further analysis.

Brown et al. (2003) proposed a statistical method to derive the steady-state loss rates of $\mathrm{NO}_{3}$ and $\mathrm{N}_{2} \mathrm{O}_{5}$, based on the field measured $\mathrm{NO}_{2}, \mathrm{O}_{3}, \mathrm{NO}_{3}$ and $\mathrm{N}_{2} \mathrm{O}_{5}$. Briefly, the production starts in $\mathrm{R} 1$, production of $\mathrm{NO}_{3}=k_{1}\left[\mathrm{NO}_{2}\right]\left[\mathrm{O}_{3}\right]$. If the $\mathrm{NO}_{3}$ and $\mathrm{N}_{2} \mathrm{O}_{5}$ are both in steady-state condition, where their total formation rate and total loss rate are in equivalent, the equation can be shown as in Eq. 4 .

$$
k_{1}\left[\mathrm{NO}_{2}\right]\left[\mathrm{O}_{3}\right]=k_{\mathrm{NO}_{3}}\left[\mathrm{NO}_{3}\right]+k_{\mathrm{N}_{2} \mathrm{O}_{5}}\left[\mathrm{~N}_{2} \mathrm{O}_{5}\right]
$$

where, the $k_{\mathrm{NO} 3}$ and $k_{\mathrm{N} 2} \mathrm{O} 5$ denote the first-order loss rates for $\mathrm{NO}_{3}$ and $\mathrm{N}_{2} \mathrm{O}_{5}$, respectively. It should be note that Eq.4 only holds when $\mathrm{NO}_{3}$ and $\mathrm{N}_{2} \mathrm{O}_{5}$ are pseudo steady state, i.e., the production and loss of $\mathrm{NO}_{3}$ and $\mathrm{N}_{2} \mathrm{O}_{5}$ are much faster than their net changes.

The steady-state lifetime of $\mathrm{NO}_{3}, \tau\left(\mathrm{NO}_{3}\right)$, can be calculated from Eq. 5, and the inverse lifetime of $\mathrm{NO}_{3}\left(\tau\left(\mathrm{NO}_{3}\right)^{-1}\right)$, also known as the total loss rate, can be redefined as in Eq.6.

$$
\begin{gathered}
\tau\left(\mathrm{NO}_{3}\right)=\frac{\left[\mathrm{NO}_{3}\right]}{k_{1}\left[\mathrm{NO}_{2}\right]\left[\mathrm{O}_{3}\right]}=\frac{\left[\mathrm{NO}_{3}\right]}{k_{\mathrm{NO}_{3}}\left[\mathrm{NO}_{3}\right]+k_{\mathrm{N}_{2} \mathrm{O}_{5}\left[\mathrm{~N}_{2} \mathrm{O}_{5}\right]}} \\
\tau\left(\mathrm{NO}_{3}\right)^{-1}=k_{\mathrm{NO}_{3}}+K_{\mathrm{eq}}\left[\mathrm{NO}_{2}\right] k_{\mathrm{N}_{2} \mathrm{O}_{5}}
\end{gathered}
$$


From Eq. 6, the inverse of $\mathrm{NO}_{3}$ lifetime can be described as a linear function of $K_{\text {eq }}\left[\mathrm{NO}_{2}\right]$. The $\tau\left(\mathrm{NO}_{3}\right)^{-1}$ and $\mathrm{Keq}_{\mathrm{e}}\left[\mathrm{NO}_{2}\right]$ were obtained from the measurement and the $k_{\mathrm{NO} 3}$ and $k_{\mathrm{N} 2 \mathrm{O} 5}$ were determined by fitting the slope and intercept of the function.

As has been mentioned, this analysis assumes the steady-state of $\mathrm{NO}_{3}$ and $\mathrm{N}_{2} \mathrm{O}_{5}$, which however, may not hold under some circumstances. For example, if the measurement location is too close to the emission source, the equilibrium may not be established and/or there is insufficient time to achieve steady-state. Here, we used a simple box model to test the validity of steady-state assumption for our measurement. In this model, $\mathrm{R} 2, \mathrm{R} 4$, and $\mathrm{R}^{\prime}$ ' were used as the production of $\mathrm{NO}_{3}$ and $\mathrm{N}_{2} \mathrm{O}_{5}$, whereas $k_{\mathrm{NO} 3}$ and $k_{\mathrm{N} 2 \mathrm{O} 5}$ determined from the field measurement were used to describe the total first-order loss rates of $\mathrm{NO}_{3}$ and $\mathrm{N}_{2} \mathrm{O}_{5}$, respectively, regardless of detailed loss pathways. According to the selected case studies in Section 3.2 below, four sets of initial input parameters were tested. The initial concentrations of $\mathrm{NO}_{3}$ and $\mathrm{N}_{2} \mathrm{O}_{5}$ were set to zero, and a nighttime mean temperature of $300 \mathrm{~K}$ was used in these runs. The model results of these four cases are presented in Figure 2. In all of the four cases, after fast accumulations at the beginning, the $\mathrm{NO}_{3}$ and $\mathrm{N}_{2} \mathrm{O}_{5}$ slowly decrease, indicating a relatively small net changing rate. Also showed in the bottom two panels of the sub-figures that the net variations of $\mathrm{NO}_{3}$ and $\mathrm{N}_{2} \mathrm{O}_{5}$ become much smaller than their production and loss rates after a short period (c.a. 15 min), suggesting that both of them are in pseudo steady-state. As the distance from the nearest major NOx emission source was approximately $15 \mathrm{~km}$ away and with a maximum wind speed of $5 \mathrm{~m} \mathrm{~s}^{-1}$, a minimum of 50 min was required for the air plume to reach the measurement site, which is probably enough for $\mathrm{NO}_{3}$ and $\mathrm{N}_{2} \mathrm{O}_{5}$ to achieve steady-state for all of our selected cases. 

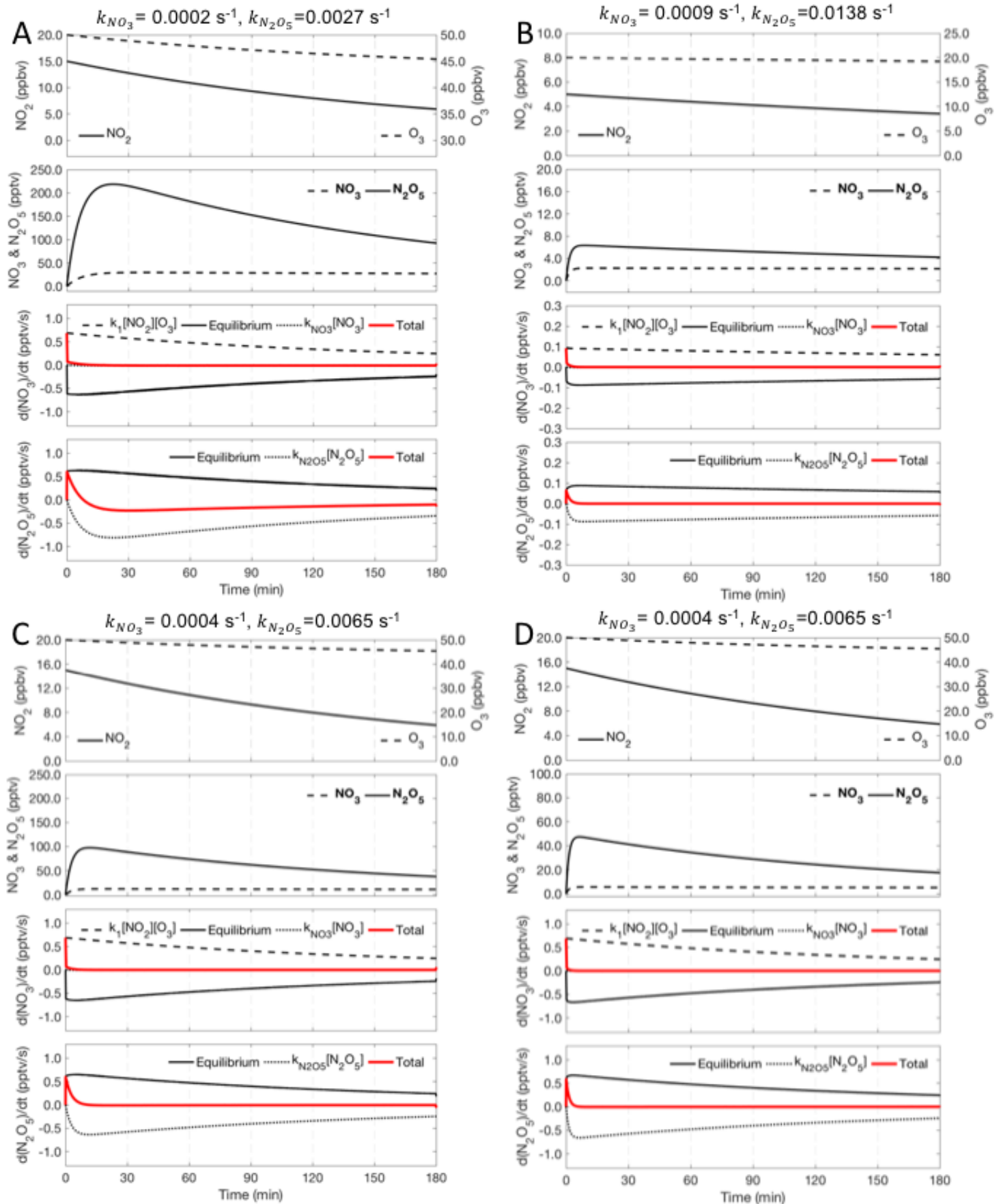

Figure 2. Verifying the steady-state of $\mathrm{NO}_{3}$ and $\mathrm{N}_{2} \mathrm{O}_{5}$. Model input parameters in A-D are obtained from the four cases shown in Section 3.2.

\subsection{Calculation of $\mathrm{OH}$ concentration}


The OH concentration was calculated according to the Ehhalt and Rohrer (2000) parameterization, which based on the function of $\mathrm{NO}_{2}$ mixing ratio, and the photolysis rates of $\mathrm{O}_{3}$ and $\mathrm{NO}_{2}$.

$$
[\mathrm{OH}]=4.1 \times 10^{9} \times\left(\mathrm{O}_{\mathrm{O}^{1} \mathrm{D}}\right)^{0.83}\left(\mathrm{JO}_{\mathrm{NO}_{2}}\right) 0^{0.19} \frac{140\left[\mathrm{NO}_{2}\right]+1}{0.41\left[\mathrm{NO}_{2}\right]^{2}+1.7\left[\mathrm{NO}_{2}\right]+1}
$$

The JNO2 is the photolysis rate of $\mathrm{NO}_{2}$ (from filter radiometer measurement), while Jo1D, photolysis rate of $\mathrm{O}_{3}$, was estimated from the Tropospheric Ultraviolet and Visible (TUV) Radiation Model and then scaled by the measured JNO2. This parameterization was developed for the summertime conditions (in Germany) with high solar intensity, relative humidity, and biogenic VOC emissions, which are quite similar to the conditions in Hong Kong, but, uncertainty may arise if photolysis of nitrous acid (HONO) is the predominant $\mathrm{OH}$ source. The calculated values were consistent with those measured in PRD region and modeled $\mathrm{OH}$ concentrations at this site (Li et al., 2018;Hofzumahaus et al., 2009), therefore, may serve as the simplified reference of $\mathrm{OH}$ levels in this study.

\section{Results \& Discussion}

\subsection{Observation of $\mathrm{NO}_{3}, \mathrm{~N}_{2} \mathrm{O}_{5}$ and $\mathrm{ClNO}_{2}$}

Figure 3 shows the time-series of $\mathrm{NO}_{3}, \mathrm{~N}_{2} \mathrm{O}_{5}$, and $\mathrm{ClNO}_{2}$ together with related trace gases and meteorological parameters for period between 23 August and 19 September 2012. Similar to the previous observations at this location (e.g. Wang et al., 2003; Wang et al., 1998), abundant of NOx (up to $51 \mathrm{ppbv}$ ) and $\mathrm{O}_{3}$ (up to $152 \mathrm{ppbv}$ ) were observed during the measurement period. These high levels of $\mathrm{NO}_{x}$ and $\mathrm{O}_{3}$ lead to the active $\mathrm{NO}_{x}-\mathrm{O}_{3}$ oxidation, thus, significant of $\mathrm{NO}_{3}$ was observed starting from sunset and decrease at sunrise, with an average nighttime concentration of $7 \pm 12$ pptv (mean \pm standard deviation). Concurrently, $\mathrm{N}_{2} \mathrm{O}_{5}$ was observed to have a mean nighttime concentration of $17 \pm 33$ pptv, 
with a maximum of 336 pptv observed on the night of 23-24 August 2012. $\mathrm{ClNO}_{2}$, a product from the $\mathrm{N}_{2} \mathrm{O}_{5}$ heterogeneous reaction, was observed with an average night-time concentration of $112 \pm 218 \mathrm{pptv}$ and can reach up to $2000 \mathrm{pptv}$ during the measurement period, suggesting that there are active $\mathrm{N}_{2} \mathrm{O}_{5}$ heterogeneous processes in the region. The detail observations of $\mathrm{ClNO}_{2}$ at this site have been reported in our previous study (Tham et al., 2014).

The higher mixing ratios of $\mathrm{NO}_{3}, \mathrm{~N}_{2} \mathrm{O}_{5}$ and $\mathrm{ClNO}_{2}$ observed at the site are typically corresponding to the northerly wind (see wind direction in Figure 3), which suggest that the polluted airmasses are coming from the urban-cores of Hong Kong and PRD regions. Detailed analysis of 24-h back trajectories calculated by Hybrid Single-Particle Lagrangian Integrated Trajectory (HYSPLIT) model (Draxler and Hess, 1998) for the measurement period reveal that the airmasses arriving at the measurement site alternately originated from the continent regions (urban areas of Hong Kong and PRD) and the sea (South China Sea). For instance, airmasses were originated from the continent regions in between 23 and 26 Aug 2012 (refer as Type Ia), and then shifted to marine origins from 29 August to 14 September 2012 (Type II) before turning into the continent origins from 15 to 20 September 2012 (Type Ib). There are specific days on 27-28 August 2012 and 18-19 September 2012 that have a mixture of continent and marine airmass, where the continental air moved onto the sea (staying on the sea for more than 12 hours) before arriving at our measurement site (Type III).

Table 1 summarizes the mean concentration for $\mathrm{N}_{2} \mathrm{O}_{5}, \mathrm{NO}_{3}, \mathrm{ClNO}_{2}, \mathrm{O}_{3}$ and $\mathrm{NO}_{2}$ and the lifetime of $\mathrm{NO}_{3}$ and $\mathrm{N}_{2} \mathrm{O}_{5}$ in different type of airmasses. Owing to the high concentrations of precursors (i.e. $\mathrm{NO}_{2}$ and $\mathrm{O}_{3}$ ), highest mixing ratios of $\mathrm{NO}_{3}, \mathrm{~N}_{2} \mathrm{O}_{5}$ and $\mathrm{ClNO}_{2}$ were measured in the continental airmasses, in contrast to their lowest concentrations observed in the pristine marine airmasses (typically close to detection limits). The mixture of continent and marine airmass, on the other hand, has moderate concentrations of $\mathrm{NO}_{3}, \mathrm{~N}_{2} \mathrm{O}_{5}$ and $\mathrm{ClNO}_{2}$, although $\mathrm{NO}_{2}$ and $\mathrm{O}_{3}$ were similar to the continental airmasses. The lifetime of $\mathrm{N}_{2} \mathrm{O}_{5}$ (and $\mathrm{NO}_{3}$ due to their internal equilibrium) in all types of masses were notably shorter than those in the earlier studies in US and Europe (e.g. Brown et al., 2006; Crowley et al., 2011; Morgan et al., 2015; Brown et al., 2009), especially in Type III airmasses, which suggested fast losses of 
$\mathrm{N}_{2} \mathrm{O}_{5}$ and $\mathrm{NO}_{3}$ at this location. In addition, higher ratios between $\mathrm{ClNO}_{2}$ and $\mathrm{N}_{2} \mathrm{O}_{5}$ were found in marine-involved airmasses, indicating more active $\mathrm{N}_{2} \mathrm{O}_{5}$ heterogeneous chemical processes, probably on the chloride-rich marine aerosols.

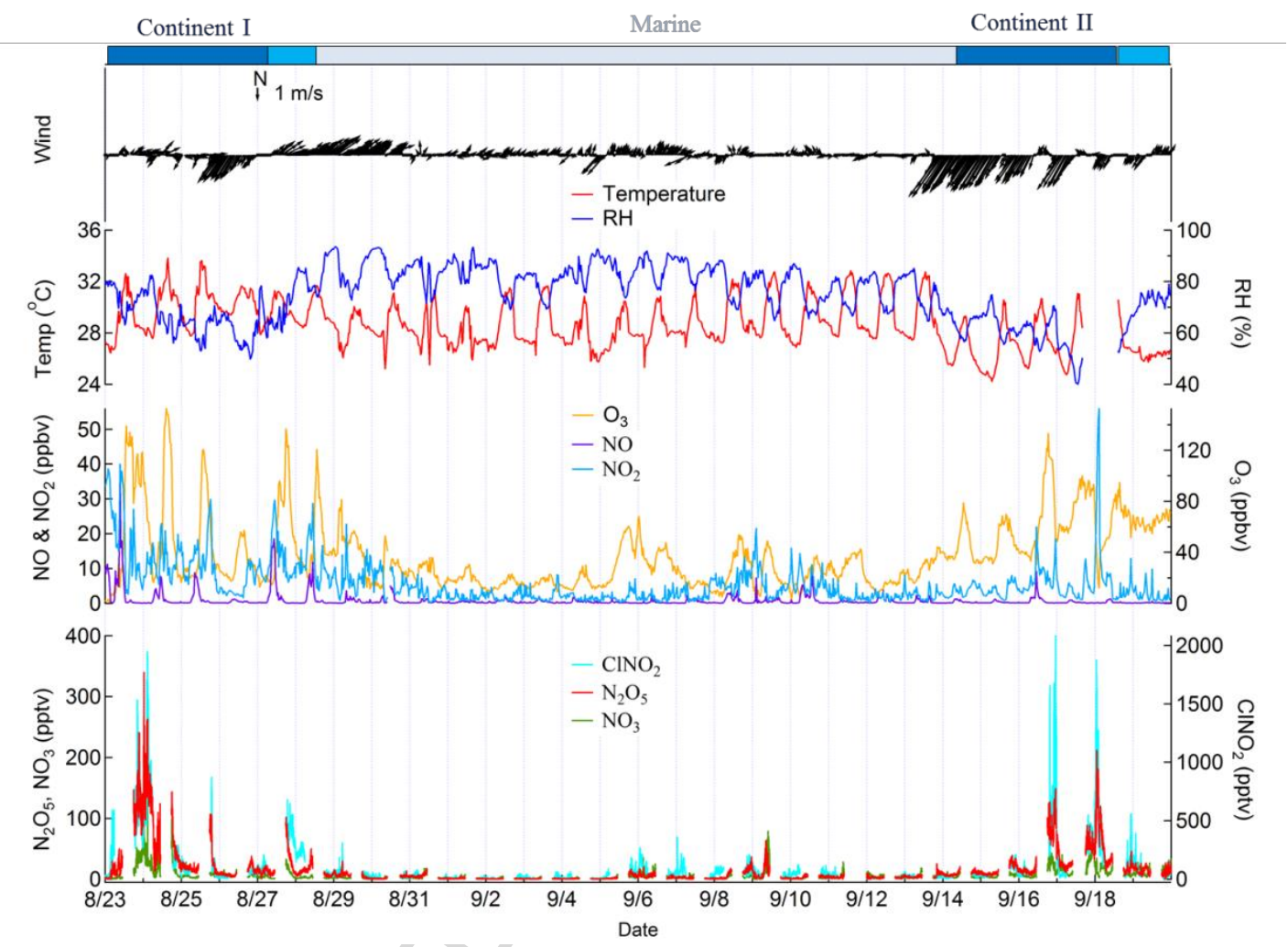

Figure 3. Temporal variations of meteorological parameters (wind, temperature, and $\mathrm{RH})$, trace gases $\left(\mathrm{CO}, \mathrm{O}_{3}, \mathrm{NO}\right.$, and $\mathrm{NO}_{2}$ ), as well as the sum of $\mathrm{NO}_{3}$ and $\mathrm{N}_{2} \mathrm{O}_{5}$ and $\mathrm{ClNO}_{2}$. Since this technique detects the sum of $\mathrm{NO}_{3}+\mathrm{N}_{2} \mathrm{O}_{5}$, the airmasses origins were determined from the 48 hours back trajectories derived from HYSPLIT.

Table 1. Mean nighttime values ( \pm standard deviation, $1 \sigma$ ) for the concentration of $\mathrm{N}_{2} \mathrm{O}_{5}, \mathrm{NO}_{3}, \mathrm{ClNO}_{2}, \mathrm{O}_{3}$, and $\mathrm{NO}_{2}$, together with $\mathrm{N}_{2} \mathrm{O}_{5}$ steady-state lifetime and $\mathrm{ClNO}_{2}$ to $\mathrm{N}_{2} \mathrm{O}_{5}$ ratio in different type of airmasses.

\begin{tabular}{lcccccccc}
\hline Airmass & Period & $\mathrm{N}_{2} \mathrm{O}_{5}$ & $\mathrm{NO}_{3}$ & $\mathrm{ClNO}_{2}$ & $\mathrm{NO}_{2}$ & $\mathrm{O}_{3}$ & $\pi^{\left(\mathrm{N}_{2} \mathrm{O}_{5}\right)^{1}}$ & $\mathrm{ClNO}_{2} / \mathrm{N}_{2} \mathrm{O}_{5}{ }^{2}$ \\
& & (pptv) & (pptv) & (pptv) & (ppbv) & (ppbv) & $(\mathbf{s})$ & \\
\hline Whole period & 23 Aug-19 Sept & $17 \pm 33$ & $7 \pm 12$ & $112 \pm 218$ & $6 \pm 7$ & $33 \pm 24$ & $76 \pm 61$ & 6.9 \\
Continental & $23-26$ Aug & $49 \pm 58$ & $14 \pm 22$ & $264 \pm 348$ & $12 \pm 9$ & $40 \pm 31$ & $119 \pm 76$ & 5.3
\end{tabular}


(Type Ia)

$\begin{array}{lrrrrrrrr}\text { Marine } & \text { 29 Aug - } 14 \text { Sept } & 4 \pm 4 & 2 \pm 3 & 33 \pm 36 & 4 \pm 4 & 22 \pm 13 & 51 \pm 43 & 9.1 \\ \begin{array}{l}\text { (Type II) } \\ \text { Continental }\end{array} & 15 \text { - } 17 \text { Sept } & 44 \pm 39 & 15 \pm 13 & 269 \pm 355 & 7 \pm 10 & 56 \pm 25 & 138 \pm 47 & 6.1 \\ \text { (Type Ib) } & & & & & & & & \\ \text { Continental+ } & \text { 27/28 Aug and } & 15 \pm 10 & 8 \pm 6 & 154 \pm 135 & 6 \pm 4 & 52 \pm 24 & 79 \pm 53 & 10.1 \\ \text { Marine } & \text { 18/19 Sept } & & & & & & & \end{array}$

\section{${ }^{1}$ similar to Eq.5, $\tau\left(\mathrm{N}_{2} \mathrm{O}_{5}\right)=\frac{\left[\mathrm{N}_{2} \mathrm{O}_{5}\right]}{k_{1}\left[\mathrm{NO}_{2}\right]\left[\mathrm{O}_{3}\right]}$.}

${ }^{2}$ mean ratio.

3.2. $\mathrm{N}_{2} \mathrm{O}_{5}$ and $\mathrm{NO}_{3}$ reactivity

With the observations of short $\mathrm{N}_{2} \mathrm{O}_{5}$ lifetimes, it is crucial to assess the dominant loss pathway of $\mathrm{N}_{2} \mathrm{O}_{5}$, either through $\mathrm{NO}_{3}$ loss reactions or $\mathrm{N}_{2} \mathrm{O}_{5}$ heterogeneous uptake, in order to further determine its importance in the atmospheric processes. We distinguished the $\mathrm{N}_{2} \mathrm{O}_{5}$ reactivity by evaluating the loss rate of $\mathrm{NO}_{3}$ and $\mathrm{N}_{2} \mathrm{O}_{5}$ predicted by the steady-state method described in Section 2.3. As aforementioned, this method may not be valid if the $\mathrm{N}_{2} \mathrm{O}_{5}$ is not in steady-state or the plume changes throughout the night, which may result in a negative intercept value. Therefore, we carefully selected the valid time period of $\mathrm{N}_{2} \mathrm{O}_{5}$ data for four different nights to represent the determined types of airmasses, namely on 24 August, representing continent airmass (Type Ia); on 9 September, representing airmass origin from marine (Type II); 16 September, representing another continent airmass (Type Ib); and the night of 18 September represents the mixture of continent and marine airmass (Type III).

Figure 4 depicts the 24-h airmass back trajectories for the selected four cases, and the loss rates of $\mathrm{NO}_{3}$ and $\mathrm{N}_{2} \mathrm{O}_{5}$ in these airmasses. The results revealed that the $\mathrm{N}_{2} \mathrm{O}_{5}$ heterogeneous loss was overwhelming the loss through the $\mathrm{NO}_{3}$ reactions. The $k_{\mathrm{N} 2 \mathrm{O} 5}$ were determined to be $0.0027 \mathrm{~s}^{-1}, 0.0138 \mathrm{~s}^{-}$ 
1, $0.0065 \mathrm{~s}^{-1}$, and $0.0139 \mathrm{~s}^{-1}$ in the Type Ia, Type II, Type Ib and Type III airmasses, respectively. The determined $k_{\mathrm{NO}}$ were more than one order of magnitude smaller, derived to be $0.0002 \mathrm{~s}^{-1}$ for Type Ia, $0.0009 \mathrm{~s}^{-1}$ for Type II, and $0.0004 \mathrm{~s}^{-1}$ for both Type Ib and Type III. The predominant loss pathway for $\mathrm{N}_{2} \mathrm{O}_{5}$ heterogeneous reaction has been observed in other marine or coastal environment $(e . g .[24,27,54-$ 56], but the absolute $\mathrm{N}_{2} \mathrm{O}_{5}$ heterogeneous loss rates in at our site are considerably faster than most of the rates reported in those studies. For example, measurement in San Francisco bay observed the $k_{\mathrm{N} 2 \mathrm{O} 5}$ in the range of $5.6 \times 10^{-5}$ to $9.8 \times 10^{-4} \mathrm{~s}^{-1}$ (Wood et al., 2005), while cruise measurements along the United States east coast and Los Angeles basin reported $\mathrm{N}_{2} \mathrm{O}_{5}$ heterogeneous loss rate in between $10^{-4}$ and $10^{-3}$ $\mathrm{s}^{-1}$ (Osthoff et al., 2008; Wagner et al., 2012). Morgan et al. (2015) observed a largest $k_{\mathrm{N} 2 \mathrm{O} 5}$ of $1 \times 10^{-3} \mathrm{~s}^{-1}$ in a plume during the aircraft measurement near London and English Channel.

Among the airmasses, the marine-influenced airmasses (i.e. Type II and Type III) were determined to have faster $\mathrm{N}_{2} \mathrm{O}_{5}$ loss rates (see Figure 4) and larger $\mathrm{ClNO}_{2}$ to $\mathrm{N}_{2} \mathrm{O}_{5}$ ratios (see Table 1 ). In other words, the $\mathrm{N}_{2} \mathrm{O}_{5}$ heterogeneous loss and production of $\mathrm{ClNO}_{2}$ were higher when the air parcel interacted with the sea than in those the airmasses originated from the continent urban areas. This implied that the marine environment was more efficient in processing the $\mathrm{N}_{2} \mathrm{O}_{5}$. It can be seen that the calculated back trajectories height for the Marine and Continent + Marine airmasses were lower than $500 \mathrm{~m}$ at least 6 hours before arriving at the site (see Figure 4), suggesting that the airmass containing $\mathrm{N}_{2} \mathrm{O}_{5}$ and $\mathrm{ClNO}_{2}$ had been processed along the surface of the ocean after the sunset. During the transport along the ocean, the $\mathrm{N}_{2} \mathrm{O}_{5}$ can either being uptake onto the sea-spray to produce $\mathrm{ClNO}_{2}$, and/or deposit onto the sea surface microlayer leading to the terminal loss of $\mathrm{N}_{2} \mathrm{O}_{5}$ (Finlayson-Pitts et al., 1989). Previous studies at this site have shown that high chloride concentrations were frequently observed in total suspended particles, PM10 and PM2.5 (Cheng et al., 2000; Lai et al., 2007). Given the observation of considerable $\mathrm{ClNO}_{2}$ concentrations (up to $680 \mathrm{pptv}$ ), and higher $\mathrm{RH}$ in these types of airmasses, which can promote heterogeneous uptake (Ammann et al., 2013; Brown et al., 2012), we believe that the heterogeneous reaction of $\mathrm{N}_{2} \mathrm{O}_{5}$ was enhanced by the sea-spray/chloride-rich aerosols. However, the importance of $\mathrm{N}_{2} \mathrm{O}_{5}$ deposition and loss mechanism on the sea surface microlayer is 
unknown in this region, thereby, more future studies are needed to quantify the roles of air-sea interactions in affecting the $\mathrm{N}_{2} \mathrm{O}_{5}$ lifetime.
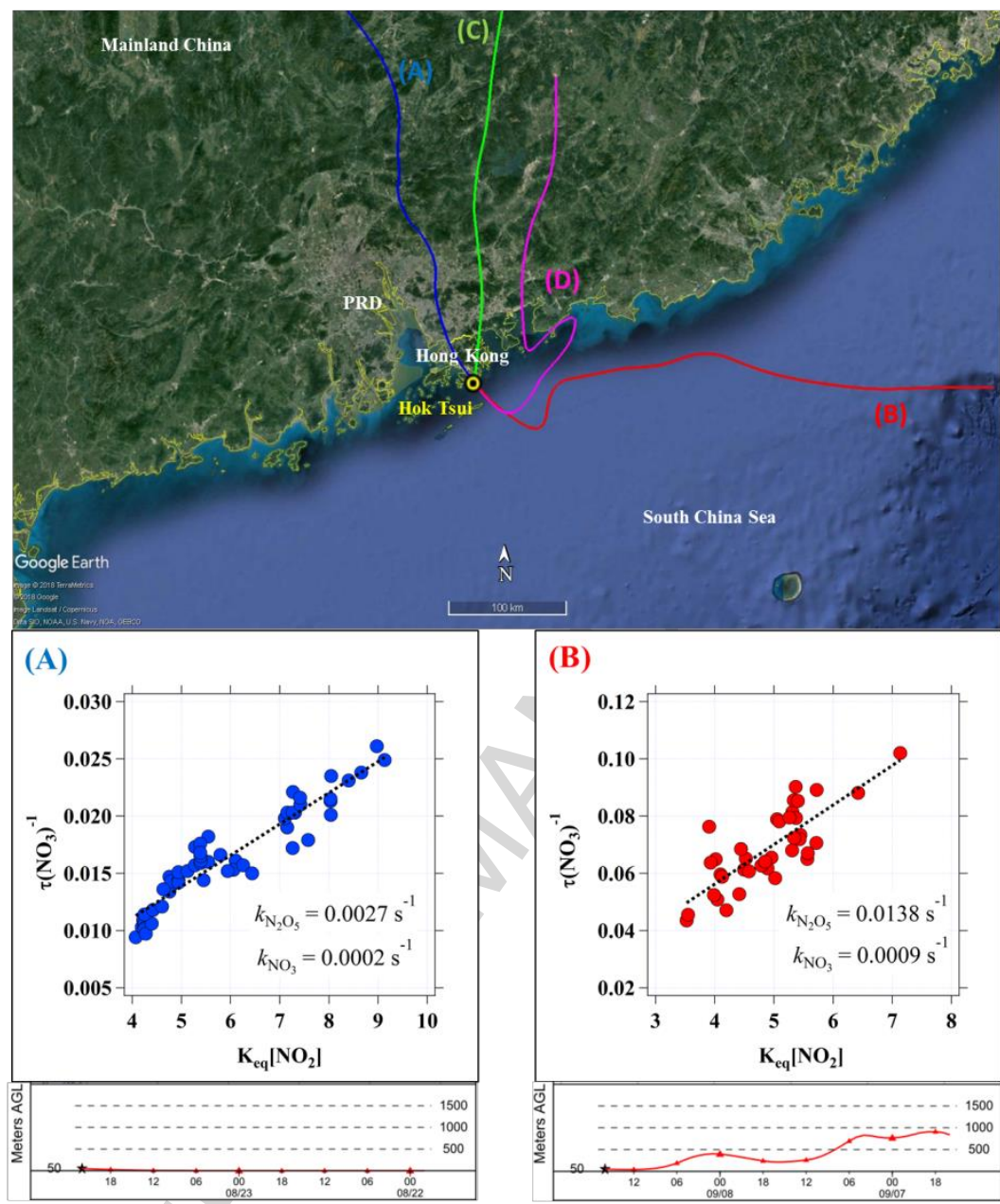

(B)
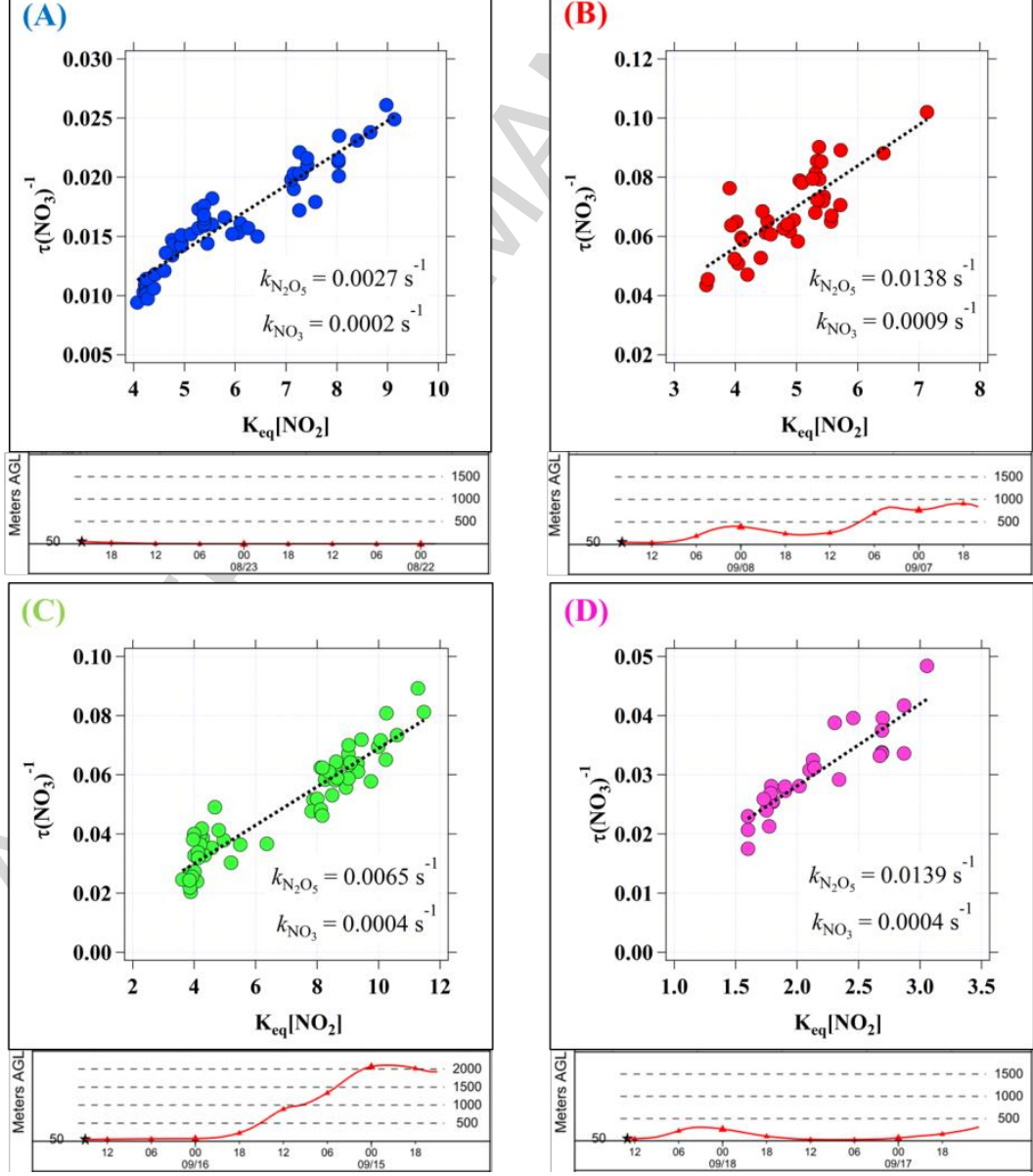

Figure 4. 48-h back-trajectories calculated from HYSPLIT for four specific nights: (A) 23 - 24 August, (B); 8 - 9 September (C); 16 - 17 September; and (D) 18 - 19 September. Scatter plots showing the determined loss rates of 
$\mathrm{NO}_{3}$ and $\mathrm{N}_{2} \mathrm{O}_{5}$ using the method described in Section 2.3. Lower panel of each plot shows the height of the airmass before arriving at the sampling site.

\subsection{Nighttime $\mathrm{NO}_{x}$ loss rate}

Heterogeneous uptake of $\mathrm{N}_{2} \mathrm{O}_{5}$ can lead to production of nitrate aerosols and $\mathrm{ClNO}_{2}$ as a cost of $\mathrm{NO} \times$. In this section, we evaluated the potential nighttime $\mathrm{NO}_{x}$ loss from the $\mathrm{N}_{2} \mathrm{O}_{5}$ heterogeneous uptake. The potential nighttime $\mathrm{NO}_{x}$ removal rate can be calculated by Eq.8, where the $\phi$ is the production yield of $\mathrm{ClNO}_{2}$, which will recycle a $\mathrm{NO}_{2}$ when photolyzed at sunrise. Setting the $\phi$ to 0 and 1 gives the upper (high) and the lower (low) limit of the $\mathrm{NO}_{x}$ removal rate $\left(L\left(\mathrm{NO}_{x}\right)\right)$ and nitrate aerosol production rate $\left(P\left(\mathrm{NO}_{3}^{-}\right)\right)$, respectively.

$$
L\left(\mathrm{NO}_{x}\right)=P\left(\mathrm{NO}_{3}^{-}\right)=(2-\phi) k_{\mathrm{N}_{2} \mathrm{O}_{5}}\left[N_{2} O_{5}\right]
$$

By using the $k_{\mathrm{N} 2 \mathrm{O} 5}$ determined above and assume that the rate is constant throughout the night, the potential nighttime $\mathrm{NO}_{x}$ removal rates for the 4 examples of airmass types were shown in Table 2.

Since significant levels of $\mathrm{ClNO}_{2}$ has been observed concurrently, the actually $\mathrm{NO}_{x}$ removal rate might be more close to the lower limits, which were $0.38 \pm 0.11$ and $0.36 \pm 0.22 \mathrm{pptv} \mathrm{s}^{-1}$ for Type Ia and Ib, $0.15 \pm 0.11 \mathrm{pptv} \mathrm{s}^{-1}$ for Type II, and $0.23 \pm 0.10 \mathrm{pptv} \mathrm{s}^{-1}$ for Type III. Although $k_{\mathrm{N} 2 \mathrm{O} 5}$ was lower in continental airmasses than in the marine one, the $L\left(\mathrm{NO}_{x}\right)$ and $P\left(\mathrm{NO}_{3}^{-}\right)$were higher owing to the more abundant $\mathrm{N}_{2} \mathrm{O}_{5}$, suggesting that $\mathrm{N}_{2} \mathrm{O}_{5}$ pathway play a more crucial role in continental airmasses. It is also important to note that, despite the moderate $L\left(\mathrm{NO}_{x}\right)$ and $P\left(\mathrm{NO}_{3}{ }^{-}\right)$in the Type III airmass, the actually influence of such airmass type might be more significant. It is possible that $\mathrm{NO}_{2}, \mathrm{O}_{3}$, and $\mathrm{N}_{2} \mathrm{O}_{5} \mathrm{had}$ experienced efficient losses before reaching our observation station. 
We further compared the lower limit of $\mathrm{NO}_{x}$ removal rates via $\mathrm{N}_{2} \mathrm{O}_{5}$ hydrolysis with the upper limit of main daytime $\mathrm{NO}_{x}$ loss rates assuming that all nitric acid produced via $\mathrm{OH}$ oxidation (R1) eventually deposit on surfaces. The $\mathrm{OH}$ was calculated using the method described in Section 2.4. Figure 5 shows the time series of the $\mathrm{NO}_{x}$ removal rates and nitrate aerosol formation rates in the four cases. In the Type Ia and $\mathrm{Ib}$ airmasses, $\mathrm{N}_{2} \mathrm{O}_{5}$ heterogeneous reaction contributed about $20-25 \%$ of the NOx removal and nitrate aerosol formation; this value dropped to $15 \%$ in the Type II airmass and increased almost to half in the Type III case. These results are consistent with the study of Yun et al. (2018) that has modeled up to $79 \%$ of $\mathrm{NO}_{2}$ loss in the nocturnal residual layer of Hong Kong was caused by the $\mathrm{N}_{2} \mathrm{O}_{5}$ heterogeneous reaction. Therefore, we conclude that the $\mathrm{N}_{2} \mathrm{O}_{5}$ heterogeneous reaction can play a significant role in affecting the $\mathrm{NO}_{x}$ lifetime in this coastal region, especially in the airmasses with continental origins.

Table 2. Mean $\mathrm{NO}_{x}$ removal rates and nitrate aerosol formation rates via $\mathrm{N}_{2} \mathrm{O}_{5}$ heterogeneous reaction during the four cases ( \pm standard deviation, $1 \sigma$ ), as well as their comparison with the adjacent daytime via $\mathrm{HNO}_{3}$ deposition pathway. The lower and higher limits of $\mathrm{N}_{2} \mathrm{O}_{5}$ pathway are calculated by assuming a unit or zero production of $\mathrm{ClNO}_{2}$, respectively; The $\mathrm{NO}_{2}+\mathrm{OH}$ values are higher limit, assuming all gas-phase $\mathrm{HNO}_{3}$ will deposit on particle surfaces.

\begin{tabular}{lcccccc}
\hline Airmass & \multicolumn{3}{c}{ via $\mathrm{N}_{2} \mathrm{O}_{5}$ heterogeneous reaction } & \multicolumn{2}{c}{ via $\mathrm{HNO}_{3}$ deposition } \\
\hline & $L\left(\mathrm{NO}_{x}\right)_{\text {low }}$ & $P\left(\mathrm{NO}_{3}\right)^{-}$low & $L\left(\mathrm{NO}_{x}\right)_{\text {high }}$ & $P\left(\mathrm{NO}_{3}\right)_{\text {high }}$ & $L\left(\mathrm{NO}_{x}\right)_{\text {high }}$ & $P\left(\mathrm{NO}_{3}\right)_{\text {high }}$ \\
& $\left(\mathrm{pptv} \mathrm{s}^{-1}\right)$ & $\left(\mu \mathrm{g} \mathrm{m}^{-3} \mathrm{~h}^{-1}\right)$ & $\left(\mathrm{pptv} \mathrm{s}^{-1}\right)$ & $\left(\mu \mathrm{g} \mathrm{m}^{-3} \mathrm{~h}^{-1}\right)$ & $\left(\mathrm{pptv} \mathrm{s}^{-1}\right)$ & $\left(\mu \mathrm{g} \mathrm{m}^{-3} \mathrm{~h}^{-1}\right)$ \\
\hline Type 1a & $0.38 \pm 0.11$ & $3.79 \pm 1.09$ & $0.76 \pm 0.22$ & $7.58 \pm 2.19$ & $1.33 \pm 0.58$ & $13.30 \pm 5.80$ \\
Type II & $0.15 \pm 0.11$ & $1.52 \pm 1.07$ & $0.29 \pm 0.22$ & $2.90 \pm 2.20$ & $0.87 \pm 0.55$ & $8.63 \pm 5.48$ \\
Type 1b & $0.36 \pm 0.22$ & $3.62 \pm 2.20$ & $0.72 \pm 0.44$ & $7.24 \pm 4.41$ & $1.14 \pm 0.56$ & $11.39 \pm 5.62$ \\
Type III & $0.23 \pm 0.10$ & $2.30 \pm 0.96$ & $0.46 \pm 0.20$ & $4.61 \pm 1.98$ & $0.25 \pm 0.20$ & $2.54 \pm 2.02$ \\
\hline
\end{tabular}




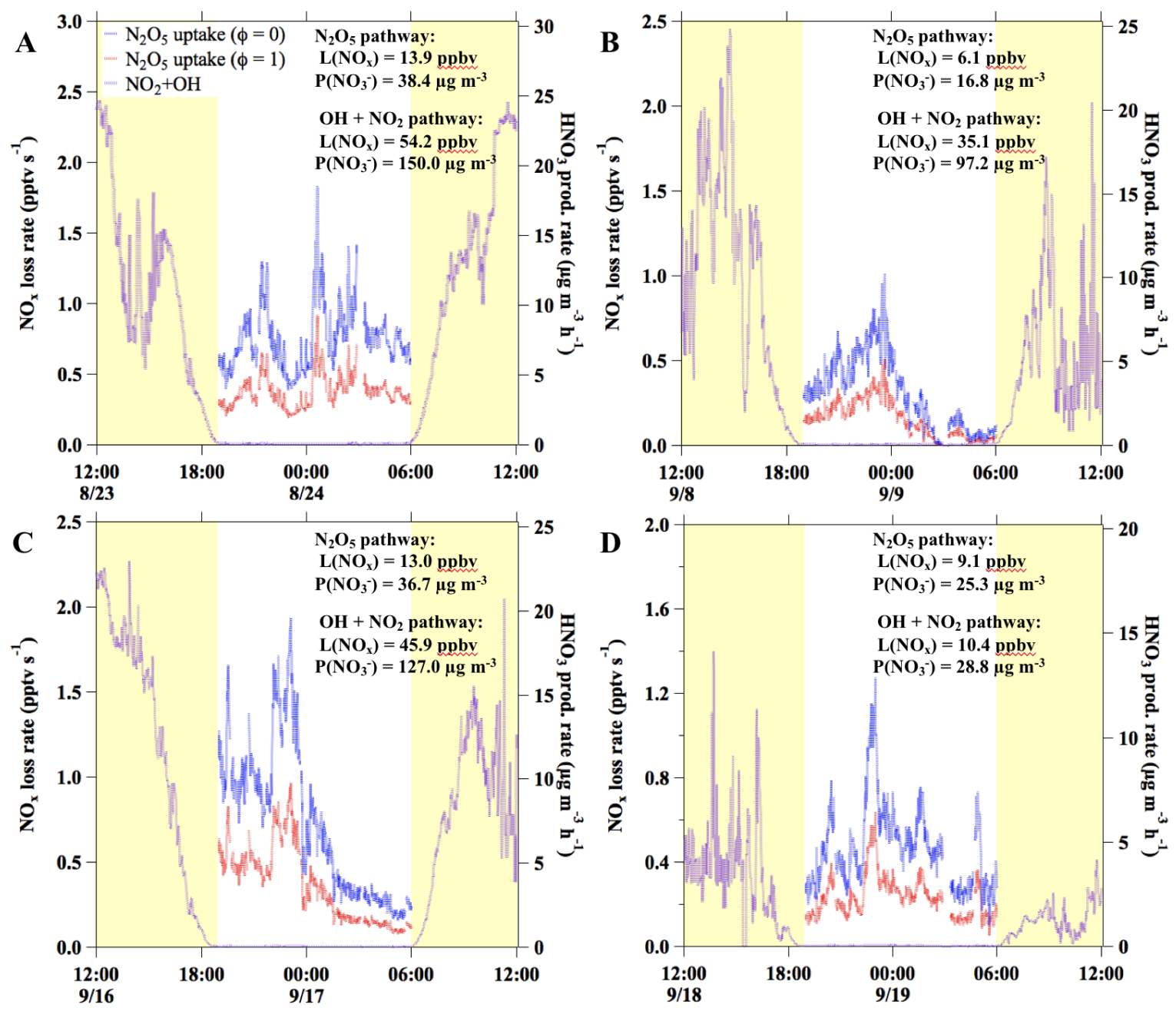

Figure 5. The $\mathrm{NO}_{x}$ removal rate in pptv s ${ }^{-1}$ (left axis) and corresponding inorganic nitrate aerosol production rate in $\mu \mathrm{g} \mathrm{m}^{-3} \mathrm{~h}^{-1}$ (right axis) for a) 23-24 August 2012 (Continent I); b) 8-9 September 2012 (Marine); c) 16-17 September 2012 (Continent II); and d) 18-19 September 2012 (Continent + Marine).

\section{Summary and conclusions}

This study presents a simultaneous measurement of $\mathrm{NO}_{3}, \mathrm{~N}_{2} \mathrm{O}_{5}$ and $\mathrm{ClNO}_{2}$ using a TD-CIMS at a ground-level coastal site of southern China during the autumn of 2012. During the measurement period, three types of airmasses were determined based on their back trajectories: purely continental air, purely marine air, and marine air with continental origin. Steady-state analysis of $\mathrm{N}_{2} \mathrm{O}_{5}$ revealed that the overall loss rate of $\mathrm{NO}_{3}$ and $\mathrm{N}_{2} \mathrm{O}_{5}$ was high in all four example types of airmasses arriving at the location. In contrast to the finding in the nocturnal residual layer that $\mathrm{NO}_{3}$ and $\mathrm{N}_{2} \mathrm{O}_{5}$ have overall 
similar loss rates (Brown et al., 2016), $\mathrm{N}_{2} \mathrm{O}_{5}$ loss dominated ( $>95 \%$ ) the overall loss and exhibited higher rates in marine air or when the air went across the sea. In such airmasses, faster loss rate of $\mathrm{N}_{2} \mathrm{O}_{5}$ and higher ratios of $\mathrm{ClNO}_{2}$ to $\mathrm{N}_{2} \mathrm{O}_{5}$ were also observed compared to continental airmasses, suggesting stronger heterogeneous reaction of $\mathrm{N}_{2} \mathrm{O}_{5}$ on chlorine-rich aerosols. Although we did not have the concurrent aerosol measurement, the higher $\mathrm{N}_{2} \mathrm{O}_{5}$ loss rate might be attributed to several reasons: 1 ) the chorine-rich and organic-poor marine aerosols; 2) the higher $\mathrm{RH}$; 3) net deposition on sea surface. The fast loss of $\mathrm{N}_{2} \mathrm{O}_{5}$ contributed to a significant fraction of $\mathrm{NO}_{x}$ removal and nitrate aerosol formation in this coastal ground-level site. Together with previous studies [Brown et al., 2016; Wang et al., 2016; Yun et al., 2018], the $\mathrm{NO}_{x}$ removal via $\mathrm{NO}_{3}$ and $\mathrm{N}_{2} \mathrm{O}_{5}$ pathways can influence the $\mathrm{NOx}$ budget and nitrate formation in a large portion of the planetary boundary layer in the coastal regions of southern China.

Author Contributions: Conceptualization, C.Y., Y.J.T. and T.W.; methodology, C.Y., Y.J.T. and X.W.; formal analysis, C.Y., Y.J.T., Q.Z., and J.D.; investigation, C.Y., Y.J.T. and Q.Z.; writing-original draft preparation, C.Y. and Y.J.T.; writing - review and editing, T.W., L.X. and Z.W.; supervision, T.W.; funding acquisition, T.W.

Funding: This work was supported by the Research Grants Council of Hong Kong (A-PolyU502/16)

Acknowledgments: The authors would like to thank Steven Poon, Zheng Xu, Much Yeung and James Chan for logistic support, and assist in preparation of the field studies.

Conflicts of Interest: The authors declare no conflict of interest. The funders had no role in the design of the study; in the collection, analyses, or interpretation of data; in the writing of the manuscript, or in the decision to publish the results. 


\section{References}

Aldener, M., Brown, S. S., Stark, H., Williams, E. J., Lerner, B. M., Kuster, W. C., Goldan, P. D., Quinn, P. K., Bates, T. S., Fehsenfeld, F. C., and Ravishankara, A. R.: Reactivity and loss mechanisms of $\mathrm{NO}_{3}$ and $\mathrm{N}_{2} \mathrm{O}_{5}$ in a polluted marine environment: Results from in situ measurements during New England Air Quality Study 2002, J. Geophys. Res.-Atmos, 111, 2006.

Ammann, M., Cox, R. A., Crowley, J. N., Jenkin, M. E., Mellouki, A., Rossi, M. J., Troe, J., and Wallington, T. J.: Evaluated kinetic and photochemical data for atmospheric chemistry: Volume VI - heterogeneous reactions with liquid substrates, Atmos. Chem. Phys., 13, 8045-8228, 10.5194/acp-13-8045-2013, 2013.

Bertram, T., and Thornton, J.: Toward a general parameterization of $\mathrm{N} 2 \mathrm{O} 5$ reactivity on aqueous particles: the competing effects of particle liquid water, nitrate and chloride, Atmos. Chem. Phys., 9, 8351-8363, 2009.

Brown, S. S., Stark, H., and Ravishankara, A. R.: Applicability of the steady state approximation to the interpretation of atmospheric observations of $\mathrm{NO}_{3}$ and $\mathrm{N}_{2} \mathrm{O}_{5}$, J Geophys Res-Atmos, 108, 4539, $2003 \mathrm{a}$.

Brown, S. S., Stark, H., Ryerson, T. B., Williams, E. J., Nicks Jr, D. K., Trainer, M., Fehsenfeld, F. C., and Ravishankara, A.: Nitrogen oxides in the nocturnal boundary layer: Simultaneous in situ measurements of NO3, N2O5, NO2, NO, and O3, J. Geophys. Res.-Atmos, 108, 2003 b.

Brown, S. S., Ryerson, T. B., Wollny, A. G., Brock, C. A., Peltier, R., Sullivan, A. P., Weber, R. J., Dube, W. P., Trainer, M., Meagher, J. F., Fehsenfeld, F. C., and Ravishankara, A. R.: Variability in nocturnal nitrogen oxide processing and its role in regional air quality, Science, 311, 67-70, 2006.

Brown, S. S., Dube, W. P., Fuchs, H., Ryerson, T. B., Wollny, A. G., Brock, C. A., Bahreini, R., Middlebrook, A. M., Neuman, J. A., Atlas, E., Roberts, J. M., Osthoff, H. D., Trainer, M., Fehsenfeld, F. C., and Ravishankara, A. R.: Reactive uptake coefficients for N2O5 determined from aircraft measurements during the Second Texas Air Quality Study: Comparison to current model parameterizations, J Geophys Res-Atmos, 114, 2009.

Brown, S. S., Dubé, W. P., Peischl, J., Ryerson, T. B., Atlas, E., Warneke, C., De Gouw, J. A., te Lintel Hekkert, S., Brock, C. A., and Flocke, F.: Budgets for nocturnal VOC oxidation by nitrate radicals aloft during the 2006 Texas Air Quality Study, J. Geophys. Res.-Atmos, 116, 2011.

Brown, S. S., and Stutz, J.: Nighttime radical observations and chemistry, Chem. Soc. Rev., 41, 6405-6447, 10.1039/c2cs35181a, 2012.

Brown, S. S., Dubé, W. P., Tham, Y. J., Zha, Q., Xue, L., Poon, S., Wang, Z., Blake, D. R., Tsui, W., and Parrish, D. D.: Nighttime Chemistry at a High Altitude Site Above Hong Kong, J. Geophys. Res.-Atmos, 121, 2016.

Cheng, Z., Lam, K., Chan, L., Wang, T., and Cheng, K.: Chemical characteristics of aerosols at coastal station in Hong Kong. I. Seasonal variation of major ions, halogens and mineral dusts between 1995 and 1996, Atmos. Environ., 34, 2771-2783, 2000.

Crowley, J., Thieser, J., Tang, M., Schuster, G., Bozem, H., Beygi, Z. H., Fischer, H., Diesch, J.-M., Drewnick, F., and Borrmann, S.: Variable lifetimes and loss mechanisms for NO3 and N2O5 during the DOMINO campaign: contrasts between marine, urban and continental air, Atmos. Chem. Phys., 11, 10853, 2011.

Draxler, R. R., and Hess, G.: An overview of the HYSPLIT_4 modelling system for trajectories, Australian meteorological magazine, 47, 295-308, 1998.

Ehhalt, D. H., and Rohrer, F.: Dependence of the $\mathrm{OH}$ concentration on solar UV, J. Geophys. Res.-Atmos, 105, 3565-3571, 2000.

Finlayson-Pitts, B., Ezell, M., and Pitts Jr, J.: Formation of chemically active chlorine compounds by reactions of atmospheric $\mathrm{NaCl}$ particles with gaseous $\mathrm{N}_{2} \mathrm{O}_{5}$ and $\mathrm{ClONO}_{2}$, Nature, 337, 241, 1989. 
Gaston, C. J., Thornton, J. A., and Ng, N. L.: Reactive uptake of $\mathrm{N}_{2} \mathrm{O}_{5}$ to internally mixed inorganic and organic particles: the role of organic carbon oxidation state and inferred organic phase separations, Atmos. Chem. Phys, 14, 5693-5707, 2014.

Gaston, C. J., and Thornton, J. A.: Reacto-Diffusive Length of N2O5 in Aqueous Sulfate- and ChlorideContaining Aerosol Particles, J. Phys. Chem. A, 120, 1039-1045, 2016.

Hahn, J., Luther, K., and Troe, J.: Experimental and theoretical study of the temperature and pressure dependences of the recombination reactions $\mathrm{O}+\mathrm{NO}_{2}(+\mathrm{M})->\mathrm{NO}_{3}(+\mathrm{M})$ and $\mathrm{NO}_{2}+\mathrm{NO}_{3}(+\mathrm{M})->\mathrm{N}_{2} \mathrm{O}_{5}(+\mathrm{M})$, Phys. Chem. Chem. Phys., 2, 5098-5104, DOI 10.1039/b005756h, 2000.

Hofzumahaus, A., Rohrer, F., Lu, K., Bohn, B., Brauers, T., Chang, C.-C., Fuchs, H., Holland, F., Kita, K., and Kondo, Y.: Amplified trace gas removal in the troposphere, science, 324, 1702-1704, 2009.

Hoyle, C. R., Boy, M., Donahue, N. M., Fry, J. L., Glasius, M., Guenther, A., Hallar, A. G., Hartz, K. H., Petters, M. D., Petaja, T., Rosenoern, T., and Sullivan, A. P.: A review of the anthropogenic influence on biogenic secondary organic aerosol, Atmos. Chem. Phys., 11, 321-343, 10.5194/acp-11-321-2011, 2011.

Kercher, J., Riedel, T., and Thornton, J.: Chlorine activation by N 2 O 5: simultaneous, in situ detection of $\mathrm{ClNO}_{2}$ and $\mathrm{N}_{2} \mathrm{O}_{5}$ by chemical ionization mass spectrometry, Atmos. Meas. Tech., 2, 193-204, 2009.

Lai, S., Zou, S., Cao, J., Lee, S., and Ho, K.: Characterizing ionic species in PM2.5 and PM10 in four Pearl River Delta cities, South China, J Environ Sci-China, 19, 939-947, 2007.

Lee, B. H., Mohr, C., Lopez-Hilfiker, F. D., Lutz, A., Hallquist, M., Lee, L., Romer, P., Cohen, R. C., Iyer, S., Kurten, T., Hu, W., Day, D. A., Campuzano-Jost, P., Jimenez, J. L., Xu, L., Ng, N. L., Guo, H., Weber, R. J., Wild, R. J., Brown, S. S., Koss, A., de Gouw, J., Olson, K., Goldstein, A. H., Seco, R., Kim, S., McAvey, K., Shepson, P. B., Starn, T., Baumann, K., Edgerton, E. S., Liu, J., Shilling, J. E., Miller, D. O., Brune, W., Schobesberger, S., D'Ambro, E. L., and Thornton, J. A.: Highly functionalized organic nitrates in the southeast United States: Contribution to secondary organic aerosol and reactive nitrogen budgets, Proc. Natl. Acad. Sci. U S A, 113, 1516-1521, 10.1073/pnas.1508108113, 2016.

Li, Z., Xue, L., Yang, X., Zha, Q., Tham, Y. J., Yan, C., Louie, P. K., Luk, C. W., Wang, T., and Wang, W.: Oxidizing capacity of the rural atmosphere in Hong Kong, Southern China, Sci. Total. Environ., 612, 1114-1122, 2018.

Lucas, D., and Prinn, R.: Parametric sensitivity and uncertainty analysis of dimethylsulfide oxidation in the clearsky remote marine boundary layer, Atmos. Chem. and Phys., 5, 1505-1525, 2005.

Matsumoto, J., Imagawa, K., Imai, H., Kosugi, N., Ideguchi, M., Kato, S., and Kajii, Y.: Nocturnal sink of NOx via $\mathrm{NO}_{3}$ and $\mathrm{N}_{2} \mathrm{O}_{5}$ in the outflow from a source area in Japan, Atmos. Environ., 40, 6294-6302, https://doi.org/10.1016/j.atmosenv.2006.05.045, 2006.

McDuffie, E. E., Fibiger, D. L., Dubé, W. P., Lopez-Hilfiker, F., Lee, B. H., Thornton, J. A., Shah, V., Jaeglé, L., Guo, H., and Weber, R. J.: Heterogeneous N2O5 uptake during winter: Aircraft measurements during the 2015 WINTER campaign and critical evaluation of current parameterizations, J. Geophys. Res.-Atmos, 123, 43454372, 2018.

Morgan, W. T., Ouyang, B., Allan, J. D., Aruffo, E., Di Carlo, P., Kennedy, O. J., Lowe, D., Flynn, M. J., Rosenberg, P. D., Williams, P. I., Jones, R., McFiggans, G. B., and Coe, H.: Influence of aerosol chemical composition on $\mathrm{N}_{2} \mathrm{O}_{5}$ uptake: airborne regional measurements in northwestern Europe, Atmos. Chem. Phys., 15, 973-990, 10.5194/acp-15-973-2015, 2015.

Ng, N. L., Brown, S. S., Archibald, A. T., Atlas, E., Cohen, R. C., Crowley, J. N., Day, D. A., Donahue, N. M., Fry, J. L., Fuchs, H., Griffin, R. J., Guzman, M. I., Herrmann, H., Hodzic, A., Iinuma, Y., Jimenez, J. L., KiendlerScharr, A., Lee, B. H., Luecken, D. J., Mao, J. Q., McLaren, R., Mutzel, A., Osthoff, H. D., Ouyang, B., PicquetVarrault, B., Platt, U., Pye, H. O. T., Rudich, Y., Schwantes, R. H., Shiraiwa, M., Stutz, J., Thornton, J. A., Tilgner, A., Williams, B. J., and Zaveri, R. A.: Nitrate radicals and biogenic volatile organic compounds: 
oxidation, mechanisms, and organic aerosol, Atmos. Chem. Phys., 17, 2103-2162, 10.5194/acp-17-2103-2017, 2017.

Osthoff, H. D., Roberts, J. M., Ravishankara, A., Williams, E. J., Lerner, B. M., Sommariva, R., Bates, T. S., Coffman, D., Quinn, P. K., and Dibb, J. E.: High levels of nitryl chloride in the polluted subtropical marine boundary layer, Nature Geosci., 1, 324, 2008.

Ramanathan, V., Crutzen, P., Kiehl, J., and Rosenfeld, D.: Aerosols, climate, and the hydrological cycle, science, 294, 2119-2124, 2001.

Riedel, T., Bertram, T., Ryder, O., Liu, S., Day, D., Russell, L., Gaston, C., Prather, K., and Thornton, J.: Direct $\mathrm{N}_{2} \mathrm{O}_{5}$ reactivity measurements at a polluted coastal site, Atmos. Chem. Phys., 12, 2959-2968, 2012.

Rollins, A. W., Kiendler-Scharr, A., Fry, J. L., Brauers, T., Brown, S. S., Dorn, H. P., Dubé, W. P., Fuchs, H., Mensah, A., Mentel, T. F., Rohrer, F., Tillmann, R., Wegener, R., Wooldridge, P. J., and Cohen, R. C.: Isoprene oxidation by nitrate radical: alkyl nitrate and secondary organic aerosol yields, Atmos. Chem. Phys., 9, 66856703, 10.5194/acp-9-6685-2009, 2009.

Ryder, O. S., Ault, A. P., Cahill, J. F., Guasco, T. L., Riedel, T. P., Cuadra-Rodriguez, L. A., Gaston, C. J., Fitzgerald, E., Lee, C., and Prather, K. A.: On the role of particle inorganic mixing state in the reactive uptake of N2O5 to ambient aerosol particles, Environ. Sci. Techno., 48, 1618-1627, 2014.

Slusher, D. L., Huey, L. G., Tanner, D. J., Flocke, F. M., and Roberts, J. M.: A thermal dissociation-chemical ionization mass spectrometry (TD-CIMS) technique for the simultaneous measurement of peroxyacyl nitrates and dinitrogen pentoxide, J. Geophys. Res.-Atmos, 109, 2004.

Tang, M., Huang, X., Lu, K., Ge, M., Li, Y., Cheng, P., Zhu, T., Ding, A., Zhang, Y., and Gligorovski, S.: Heterogeneous reactions of mineral dust aerosol: implications for tropospheric oxidation capacity, Atmos. Chem. Phys., 17, 11727-11777, 2017.

Thaler, R. D., Mielke, L. H., and Osthoff, H. D.: Quantification of nitryl chloride at part per trillion mixing ratios by thermal dissociation cavity ring-down spectroscopy, Anal. Chem., 83, 2761-2766, 2011.

Tham, Y. J., Yan, C., Xue, L. K., Zha, Q. Z., Wang, X. F., and Wang, T.: Presence of high nitryl chloride in Asian coastal environment and its impact on atmospheric photochemistry, Chinese Sci. Bull., 59, 356-359, 10.1007/s11434-013-0063-y, 2014.

Tham, Y. J., Wang, Z., Li, Q., Yun, H., and Wang, T.: Significant concentrations of nitryl chloride sustained in the morning: Investigations of the causes and impacts on ozone production in a polluted region of northern China, Atmos. Chem. Phys., 16, 1-34, 2016.

Tham, Y. J., Wang, Z., Li, Q., Wang, W., Wang, X., Lu, K., Ma, N., Yan, C., Kecorius, S., and Wiedensohler, A.: Heterogeneous $\mathrm{N}_{2} \mathrm{O}_{5}$ uptake coefficient and production yield of $\mathrm{ClNO}_{2}$ in polluted northern China: roles of aerosol water content and chemical composition, Atmos. Chem. Phys., 18, 13155-13171, 2018.

Viggiano, A., Davidson, J., Fehsenfeld, F., and Ferguson, E.: Rate constants for the collisional dissociation of $\mathrm{N}_{2} \mathrm{O}_{5}$ by $\mathrm{N}_{2}$, J. Chem. Phys., 74, 6113-6125, 1981.

Wagner, N., Riedel, T., Roberts, J., Thornton, J., Angevine, W., Williams, E., Lerner, B., Vlasenko, A., Li, S., and Dube, W.: The sea breeze/land breeze circulation in Los Angeles and its influence on nitryl chloride production in this region, J. Geophys. Res.-Atmos, 117, 2012.

Wang, H., Lu, K., Chen, X., Zhu, Q., Chen, Q., Guo, S., Jiang, M., Li, X., Shang, D., Tan, Z., Wu, Y., Wu, Z., Zou, Q., Zheng, Y., Zeng, L., Zhu, T., Hu, M., and Zhang, Y.: High $\mathrm{N}_{2} \mathrm{O}_{5}$ Concentrations Observed in Urban Beijing: Implications of a Large Nitrate Formation Pathway, Environ. Sci. Techno. Lett, 4, 416-420, 10.1021/acs.estlett.7b00341, 2017a. 
Wang, T., Lam, K., Lee, A. S., Pang, S., and Tsui, W.: Meteorological and chemical characteristics of the photochemical ozone episodes observed at Cape D’Aguilar in Hong Kong, J. Appl. Meteorol. Climatol., 37, 1167 $1178,1998$.

Wang, T., Ding, A., Blake, D., Zahorowski, W., Poon, C., and Li, Y.: Chemical characterization of the boundary layer outflow of air pollution to Hong Kong during February-April 2001, J. Geophys. Res.-Atmos, $108,2003$.

Wang, T., Guo, H., Blake, D., Kwok, Y., Simpson, I., and Li, Y.: Measurements of trace gases in the inflow of South China Sea background air and outflow of regional pollution at Tai O, Southern China, J Atmos. Chem., 52, 295, 2005.

Wang, T., Ding, A., Gao, J., and Wu, W. S.: Strong ozone production in urban plumes from Beijing, China, Geophys. Res. Lett., 33, 2006.

Wang, T., Wei, X. L., Ding, A. J., Poon, C. N., Lam, K. S., Li, Y. S., Chan, L. Y., and Anson, M.: Increasing surface ozone concentrations in the background atmosphere of Southern China, 1994-2007, Atmos. Chem. Phys., 9, 6217-6227, 10.5194/acp-9-6217-2009, 2009a.

Wang, T., Wei, X. L., Ding, A. J., Poon, C. N., Lam, K. S., Li, Y. S., Chan, L. Y., and Anson, M.: Increasing surface ozone concentrations in the background atmosphere of Southern China, 1994-2007, Atmos. Chem. Phys., 9, 6217-6227, DOI 10.5194/acp-9-6217-2009, 2009b.

Wang, T., Nie, W., Gao, J., Xue, L., Gao, X., Wang, X., Qiu, J., Poon, C., Meinardi, S., and Blake, D.: Air quality during the 2008 Beijing Olympics: secondary pollutants and regional impact, Atmos. Chem. Phys. 10, 7603-7615, 2010 .

Wang, T., Tham, Y. J., Xue, L., Li, Q., Zha, Q., Wang, Z., Poon, S. C. N., Dubé, W. P., Blake, D. R., Louie, P. K. K., Luk, C. W. Y., Tsui, W., and Brown, S. S.: Observations of nitryl chloride and modeling its source and effect on ozone in the planetary boundary layer of southern China, J. Geophys. Res.-Atmos, 121, 2476-2489, 10.1002/2015jd024556, 2016.

Wang, X., Wang, T., Yan, C., Tham, Y. J., Xue, L., Xu, Z., and Zha, Q.: Large daytime signals of N2O5 and NO3 inferred at $62 \mathrm{amu}$ in a TD-CIMS: Chemical interference or a real atmospheric phenomenon, Atmos. Meas. Tech., 2014.

Wang, X., Wang, H., Xue, L., Wang, T., Wang, L., Gu, R., Wang, W., Tham, Y. J., Wang, Z., Yang, L., Chen, J., and Wang, W.: Observations of $\mathrm{N}_{2} \mathrm{O}_{5}$ and $\mathrm{ClNO}_{2}$ at a polluted urban surface site in North China: $\mathrm{High}_{2} \mathrm{~N}_{5}$ uptake coefficients and low $\mathrm{ClNO}_{2}$ product yields, Atmos. Environ., 156, 125-134, https://doi.org/10.1016/j.atmosenv.2017.02.035, 2017b.

Wang, Z., Wang, W., Tham, Y. J., Li, Q., Wang, H., Wen, L., Wang, X., and Wang, T.: Fast heterogeneous $\mathrm{N}_{2} \mathrm{O}_{5}$ uptake and $\mathrm{ClNO}_{2}$ production in power plant and industrial plumes observed in the nocturnal residual layer over the North China Plain, Atmos. Chem. Phys., 17, 12361-12378, 10.5194/acp-17-12361-2017, 2017c.

Wood, E., Bertram, T., Wooldridge, P., and Cohen, R.: Measurements of $\mathrm{N}_{2} \mathrm{O}_{5}, \mathrm{NO}_{2}$, and $\mathrm{O}_{3}$ east of the San Francisco Bay, Atmos. Chem. Phys., 5, 483-491, 2005.

Xu, Z., Wang, T., Xue, L., Louie, P. K., Luk, C. W., Gao, J., Wang, S., Chai, F., and Wang, W.: Evaluating the uncertainties of thermal catalytic conversion in measuring atmospheric nitrogen dioxide at four differently polluted sites in China, Atmos. Environ., 2012.

Xue, L., Gu, R., Wang, T., Wang, X., Saunders, S., Blake, D., Louie, P. K., Luk, C. W., Simpson, I., and Xu, Z.: Oxidative capacity and radical chemistry in the polluted atmosphere of Hong Kong and Pearl River Delta region: analysis of a severe photochemical smog episode, Atmos. Chem. Phys., 2016.

Yan, C., Nie, W., Aijala, M., Rissanen, M. P., Canagaratna, M. R., Massoli, P., Junninen, H., Jokinen, T., Sarnela, N., Hame, S. A. K., Schobesberger, S., Canonaco, F., Yao, L., Prevot, A. S. H., Petaja, T., Kulmala, M., Sipila, M., Worsnop, D. R., and Ehn, M.: Source characterization of highly oxidized multifunctional compounds in a 
boreal forest environment using positive matrix factorization, Atmos. Chem. Phys., 16, 12715-12731, 10.5194/acp-16-12715-2016, 2016.

Yun, H., Wang, T., Wang, W., Tham, Y. J., Li, Q., Wang, Z., and Poon, S.: Nighttime NOx loss and CINO2 formation in the residual layer of a polluted region: Insights from field measurements and an iterative box model, Sci. Total Environ., 622-623, 727, 2017. 


\section{Graphical abstract}

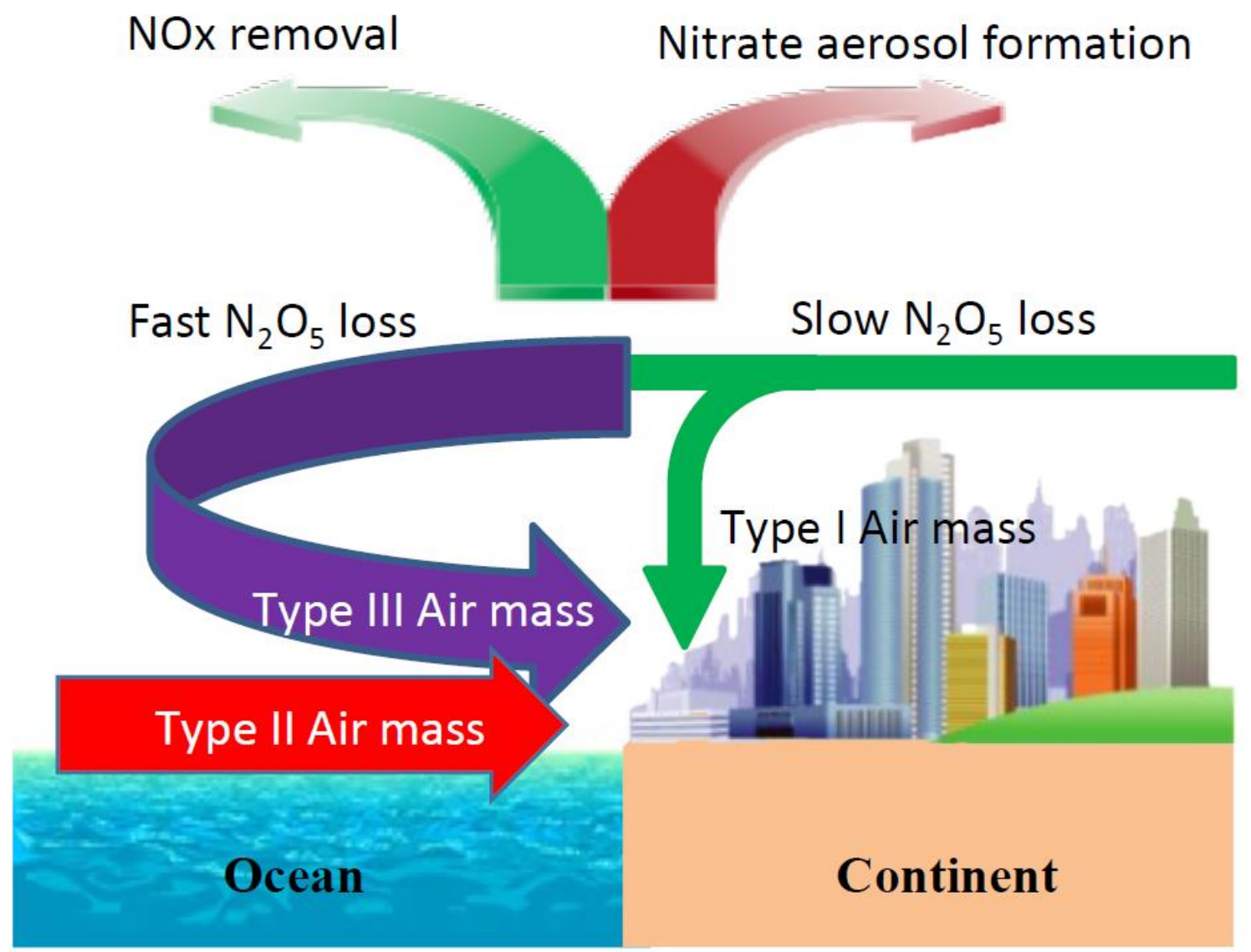

